\title{
A Western Reversal Since the Neolithic? The Long-Run Impact of Early Agriculture
}

Ola Olsson and Christopher Paik

In this article we document a reversal of fortune within the Western agricultural core, showing that regions which made early transition to Neolithic agriculture are now poorer than regions that made the transition later. The finding contrasts recent influential works emphasizing the beneficial role of early transition. Using data from a large number of carbon-dated Neolithic sites throughout the Western agricultural area, we determine approximate transition dates for about 60 countries, 280 medium-sized regions, and 1,400 small regions. Our empirical analysis shows that there is a robust negative, reduced-form relationship between years since transition to agriculture and contemporary levels of income both across and within countries. Our results further indicate that the reversal had started to emerge already before the era of European colonization.

$\mathrm{T}^{\mathrm{s}}$ he Neolithic Revolution was a momentous event which introduced agriculture to humans around 12,000 BP. ${ }^{1}$ It marked for the first time humans' departure from their hunter-gatherer lifestyle for agriculture and sedentary living. A striking feature of comparative economic development today is that regions which made an early transition to agriculture and to civilization, such as current Iraq, Egypt, and Syria, are now relatively poor. On the other hand, regions that made a very late transition to civilization in the northern periphery of the Western cultural zone, such as Sweden and the Netherlands, currently enjoy prosperous economies.

These casual observations stand in stark contrast to some of the seminal works in the literature proposing a positive association between early agricultural transition and high income levels today. For example,

The Journal of Economic History, Vol. 80, No. 1 (March 2020). (C) The Economic History Association. doi: 10.1017/S0022050719000846. This is an Open Access article, distributed under the terms of the Creative Commons Attribution license (http://creativecommons.org/ licenses/by/4.0/), which permits unrestricted re-use, distribution, and reproduction in any medium, provided the original work is properly cited.

Ola Olsson is Professor and Vice Dean, University of Gothenburg, Department of Economics, Box 640, 40530 Gothenburg, Sweden. E-mail: ola.olsson@economics.gu.se. Christopher Paik is Assistant Professor, New York University Abu Dhabi, Division of Social Science, PO Box 129188, NYUAD Saadiyat Island Abu Dhabi, UAE. E-mail: christopher.paik@nyu.edu.

We thank the editor, Dan Bogart, and anonymous reviewers for their feedback and guidance. We are also grateful for useful comments from Ran Abramitzky, Daron Acemoglu, Quamrul Ashraf, Lisa Blaydes, Carles Boix, Matteo Cervellati, Ernesto Dal Bo, Carl-Johan Dalgaard, Jared Diamond, James Fearon, Oded Galor, Avner Greif, Douglas Hibbs, Ian Hodder, Saumitra Jha, Timur Kuran, Nippe Lagerlöf, Anastasia Litina, Neil Malhotra, Stelios Michalopoulos, Louis Putterman, James Robinson, Gérard Roland, Jacob Shapiro, Pablo Spiller, Enrico Spolaore, Romain Wacziarg, David Weil, and from seminar participants at Berkeley Haas, Brown, East Anglia, Gothenburg, Stanford, the Zeuthen Workshop in Copenhagen, and the CAGE Workshop in Warwick. This work was supported in part by a grant from the Air Force Office of Scientific Research (AFOSR) award number FA 9550-09-1-0314.

${ }^{1} \mathrm{BP}$ refers to Before Present, where the present period is set to be the year 2000. 
Diamond (1997) in his influential work argues that the region making up the Fertile Crescent in the Middle East (roughly Israel, Lebanon, Syria, Southeastern Turkey, Iraq, and Western Iran) was the first to make the transition to agriculture by about 12,000 BP because of its superior access to plants and animals suitable for domestication. Even though other regions such as China also developed agriculture independently, the highly favorable biogeography in the Fertile Crescent and in large parts of the rest of the Western agricultural core implied that this part of the world could adopt agriculture, develop civilization, statehood, science, and military technology much earlier. By $1500 \mathrm{CE}$, these advantages of an early start allowed European countries to colonize and dominate much of the rest of the World. ${ }^{2}$

Subsequent research in the social science literature have tested the hypothesis that current income levels across the world should have a positive relationship with the timing of the agricultural transition (Hibbs and Olsson 2004; Olsson and Hibbs 2005; Putterman 2008; Ashraf, Özak, and Galor 2010; Putterman and Weil 2010; Bleaney and Dimico 2011). Most of these studies have confirmed a positive relationship on a worldwide basis, suggesting that countries which made the transition early had a long-term advantage that is still detectable in current levels of prosperity.

In this article, we present a fundamentally different argument by showing that this positive relationship in a worldwide sample, a la Diamond, can be mainly driven by differences between independent agricultural core region averages, whereas the relationship within the Western core (the region that made the transition first) is actually negative. ${ }^{3}$ In our empirical exercise, we document a strong pattern of a Western reversal of fortune from the Neolithic Revolution to the current day. Specifically, by creating a comprehensive data set on the Neolithic transition for all Western areas from Pinhasi, Fort, and Ammerman (2005), our empirical analysis suggests that regions which made early transitions to agriculture do tend to be relatively poor today in terms of GDP per capita, whereas 
regions that made late transitions are now relatively rich. On the country level, this basic finding is robust to an extensive set of geographical and historical controls. At a finer regional level, using data on 280 mediumsized and about 1,400 small regions in Europe, there is likewise an overall negative relationship within countries. In addition, we show that this reversal started to manifest itself by the Early Modern Era between 1500 and $1800 .^{4}$

Figure 1 illustrates this point and also summarizes the key insight of our article. The graph shows the bivariate relationship between log GDP per capita in 2005 and the time (in years) since agricultural transition for 158 countries. As indicated by the upward-sloping line across observations, the relationship in the figure is positive when all 158 countries are included in the regression. However, when the relationships within three agricultural core areas (Western, Sub-Saharan Africa, and East Asia, which all witnessed adoption of agriculture independently) are investigated separately, we see in the graph that they turn negative. Importantly, the figure documents in detail the negative and significant relationships within the Western core, East Asia and Sub-Saharan Africa to suggest similar empirical findings. These empirical patterns suggest that the reversal observed in our data extends beyond any regional context and differs from established claims in the literature explaining the long-run divergence in income levels as a case of Western European exceptionalism.

Given the common empirical trend observed across the different regions, we specifically focus on the Western core as it witnessed the earliest agricultural adoption and has the most Neolithic data available for analysis. The topic of the Rise of the West has also long dominated discourses in the long-term economic growth literature, posing numerous challenges and alternative explanations which we address later. In our main empirical analysis, we find that (i) there is a negative relationship between time since transition to agriculture and contemporary income levels; (ii) the relationship between time since transition to agriculture and income levels turn from a positive to a negative relationship over time; and (iii) democracy emerges earlier in countries that made a late transition to agriculture.

\footnotetext{
${ }^{4}$ Our article is related to Olsson and Paik (2016), in which we use the same archaeological data to explore how the time pattern of the agricultural transition affected historical and contemporary cultural norms along the collectivism-individualism scale. We show that a later settlement by Neolithic farmers is associated with stronger individualistic norms (a strong sense of individual agency, openness to strangers, etc.), and that this pattern can be explained by a historical out-migration process from the old agricultural core region. In the current article, we study a different long-run outcome of the same Neolithic transition process: the historical and contemporary distribution of relative income levels across the Western core region.
} 


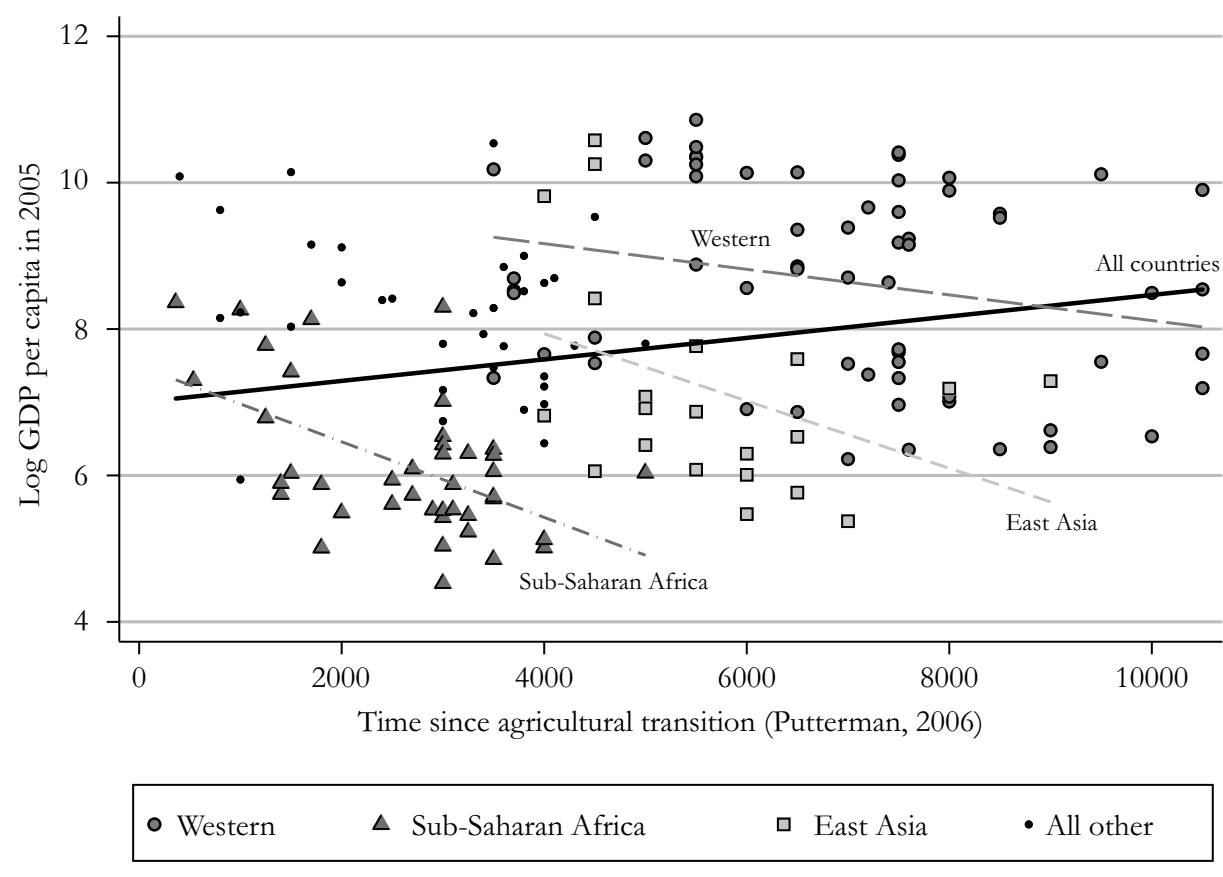

FIGURE 1

RELATIONSHIP BETWEEN LOG GDP PER CAPITA IN 2005 AND TIME SINCE AGRICULTURAL TRANSITION WITHIN THE WESTERN, SUB-SAHARAN AFRICAN, AND EAST ASIAN CORE AREAS

Notes: The figure combines three dotted lines for separate OLS regressions using the Western sample $(\mathrm{N}=62)$, the East Asian sample $(\mathrm{N}=22)$, and the Sub-Saharan African sample $(\mathrm{N}=41)$. Included in the graph are also 33 other country observations. The shape of each country indicates whether it belongs to the Western, East Asian, Sub-Saharan African, or All other category. In the total sample of 158 observations, the fitted equation is $\log$ GDP per capita in $2005=6.99^{* * *}$ $+0.000147^{* * *} \mathrm{x}$ Time since agricultural transition. $* * *=$ Significance at the .01 percent level. Source: Time since agricultural transition is taken from Putterman (2006).

In line with the evidence noted earlier, we suggest the following revised interpretation: the average income levels per capita are higher in the Western core than in other regions of the world due to the advantages of an early transition to agriculture and civilization, but in comparisons within agricultural core areas, early adoptions of agriculture led to a relatively low level of current economic development. In the original Diamond model, Neolithic biogeography played an important role for Eurasia as a whole by introducing agriculture to the hunter-gatherers in the continent earlier than in any other core areas in the world. In this article, we analyze variations within the Western core and argue that the timing of the agricultural transition may have also determined economic performance that was experienced in the long run. 
As an explanation for the reversal in the long run, we present a simple growth model building on the intuition of Borcan, Olsson, and Putterman (2018) and Lagerlöf (2016). In the model, we show that an early emergence of agriculture, with domesticated plants and animals in permanent farming villages, implied a technological and social revolution that was associated with a strong initial boost to economic development and also with the early rise of states. However, these early farming states were eventually overcome by younger states that tended to be characterized by less extractive capacity and more inclusive political institutions. These institutions, in turn, would gradually become of key importance for modern era innovation-led economic growth and for countries' ability to attain superior productivity levels.

Establishing any link between the Neolithic Revolution and current economic outcomes entails addressing numerous well-established causes of historical divergence over time. While we attempt to address them in our analysis, we openly recognize limitations in controlling for all, given the vast time span and the geographic scope covered in our analysis. What we present here are thus necessarily suggestive rather than conclusive. However, we also believe that the distinctive reversal of development levels, found both across countries and within the Western core area, warrants further discourses in the economic history literature, especially given the important topic of root of income divergence. ${ }^{5}$

The article is organized as follows. In Section 2, we first introduce our data. In Section 3, we present the main empirical findings. In Section 4 , we outline the conceptual framework that, we believe, is consistent with the development reversal that we observe in our data. Section 5 concludes.

\section{DATA}

The key explanatory variable in our empirical analysis is the time since the Neolithic transition. A basic building block in our empirical analysis is that agriculture in the Western core area-based on a composite package of wheat, barley, goats, and pigs - originated in the Fertile Crescent around 12,000 BP and then gradually spread from there northwestwards towards Europe and eastwards to Iran, Pakistan, and the Indus valley. According to a dominant tradition in archaeology, this process

\footnotetext{
${ }^{5}$ An incomplete listing of some of the most important works includes Spolaore and Wacziarg (2013), Wittfogel (1957), Jones (1981), Kennedy (1988), Mokyr (1990), North (1990), Landes (1998), Pomeranz (2000), Clark (2008), and Morris (2010).
} 
mainly had the character of a demic diffusion, whereby migrants from the Fertile Crescent colonized lands further and further away from the original center (Bellwood 2005; Pinhasi, Fort, and Ammerman 2005; Ammerman and Cavalli-Sforza 1984). ${ }^{6}$

We develop a measure for regions as well as for countries in the Western zone: Average time since agricultural transition. For the construction of both of our measures, we use a sample of calibrated C14-dates from Neolithic sites in the Near East and Europe available from Pinhasi, Fort, and Ammerman (2005). The data contain a full list of excavation sites (765 in total) that spans from the Fertile Crescent to Northwest Europe, including the location coordinates as well as calibrated C14-dates and standard deviations estimated for each site. The sites along with interpolated transition dates are presented in Figure 2. The oldest site in the sample is M'lefaat, near Mosul in Northern Iraq, dating back 12,861 years. The geographical distribution of the 765 sites shows that large parts of North Africa and Eastern Europe lack any observations. Online Appendix A provides the sites' basic characteristics and geographic distribution, as well as their potential measurement issues and various biases. Online Appendix B provides detailed descriptions of our measure, including the formulas used to calculate it. It also provides the sources and descriptive statistics for all the main and control variables used in our analysis.

Most cross-country studies that include the time since the Neolithic transition as a variable have so far used the cross-country data set in Putterman (2006). For each country, Putterman (2006) determines the date of transition by using the first attested date of Neolithic agriculture within the country's borders as stated by various specialized sources. We believe that our approach offers several advantages as compared to Putterman (2006). As far as we know, the data in Pinhasi, Fort, and Ammerman (2005) offer the most recent and most comprehensive compilation of transition dates for the Western region. Furthermore, we use the average date of transition for a country rather than the first date of transition, as in Putterman (2006). ${ }^{7}$ We believe that this practice will more accurately reflect the transition for the whole country, since there may be large discrepancies in dates of transition between regions within countries, as also acknowledged by Putterman (2006). With our approach, it is

\footnotetext{
${ }^{6}$ Demic diffusion, which proposes that agriculture typically appeared in a region as an exogenous intervention and did not arise indigenously, is often discussed in relation to cultural diffusion, whereby agriculture proposedly spreads through the diffusion of technology rather than through migration.

${ }^{7}$ We average over the calculated scores for all the cells within each country to get the country score.
} 


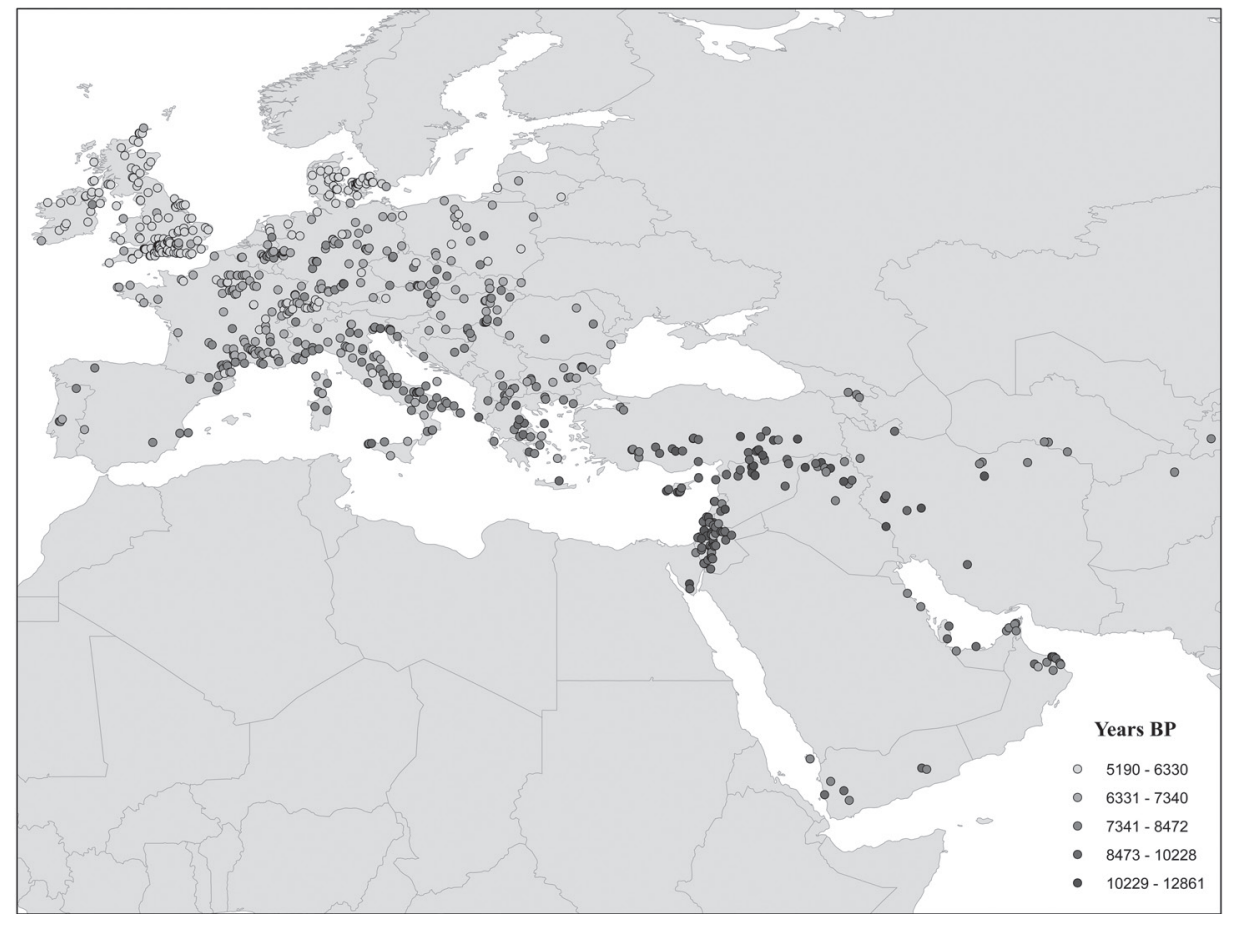

FIGURE 2

NEOLITHIC SITES AND SPREAD OF AGRICULTURE IN THE WESTERN CORE

Source: Own map based on data from Pinhasi, Fort, and Ammerman (2005).

further possible to determine transition dates on a much finer geographical level.

Average time since agricultural transition obtains the mean agricultural adoption date for each region of interest. The mean date of transition in the cross-country sample is 7,611 years BP, the minimum is 5,608 (Denmark) and the maximum 9,743 (Syria). The mean time since agricultural transition in our cross-regional sample of intra-state regions is 7,050 years with a range from 5,598 to 10,290 . This translates into a mean adoption date of 5,050 BCE and a first adoption date of 8,290 BCE.

\section{EMPIRICAL FINDINGS}

Time Since Transition to Agriculture and Contemporary Development

We first document a negative relationship within the Western agricultural core area between time since transition to agriculture and contemporary levels of economic development. Table 1, Column (1) presents 
TABLE 1

BASELINE RESULT

\begin{tabular}{lcc}
\hline & Country Level & NUTS2-Regions \\
\cline { 2 - 3 } & \multicolumn{1}{c}{ DV: Log GDP per Capita in 2005 } \\
\hline Average time since agricultural transition & $-0.492^{* * *}$ & $-0.406^{* * *}$ \\
& $(0.133)$ & $(0.032)$ \\
Conley SE & {$[0.179]$} & {$[0.074]$} \\
Constant & $12.435^{* * *}$ & $12.632^{* * *}$ \\
& $(0.984)$ & $(0.219)$ \\
Observations & 64 & 283 \\
\hline
\end{tabular}

Notes: The estimator is OLS, robust standard errors in parentheses. In calculating Conley standard errors (in square brackets), we assume that spatial autocorrelation exists among observations which are within ten degrees of each other. ${ }^{* * *} \mathrm{p}<0.01,{ }^{* *} \mathrm{p}<0.05,{ }^{*} \mathrm{p}<0.1$. The sample is all countries specified as Western in the text with available data.

Source: See Online Appendix B for data sources.

the country-level results, and Figure 3 Panel (a) shows the relationship between Log GDP per capita in 2005 and Average time since agricultural transition. ${ }^{8}$ The base sample includes Western countries in Europe, Middle East, North Africa, and Southwestern Asia that belonged to the Western core of agricultural diffusion. Conley (1999) standard errors are included in all specifications to consider potential spatial correlations. The coefficient estimate is -0.492 and strongly significant. This means that a $1,000-$ year earlier transition to agriculture is associated with approximately a 39 percent lower GDP per capita. The numbers imply that if a country close to the mean time since transition such as Italy had experienced the transition to agriculture in 8,300 BP instead of in the actual year 7,300 BP, their GDP per capita in 2005 would have been 11,826 \$US instead of 19,386 \$US. The economic significance is thus also quite strong.

Studies within the tradition of long-run development typically include geographical control variables together with their main variable of interest. However, no consensus has yet emerged on exactly what variables to include, and theory has not provided a definitive guide. For example, latitude may be strongly correlated with income today, but we do not find that controlling for other geographic correlates, there is basis for believing that a northern location per se should give an advantage for economic development. Table 2 presents a series of results showing

\footnotetext{
${ }^{8}$ Eurostat provides data based on nomenclature of territorial units for statistics (NUTS), in which NUTS1 refers to the state, and NUTS2 and NUTS3 represent disaggregated intra-state administrative divisions. Olsson and Paik (2019) provide replication files for all the tables and figures presented in this paper.
} 
a) 64 Countries

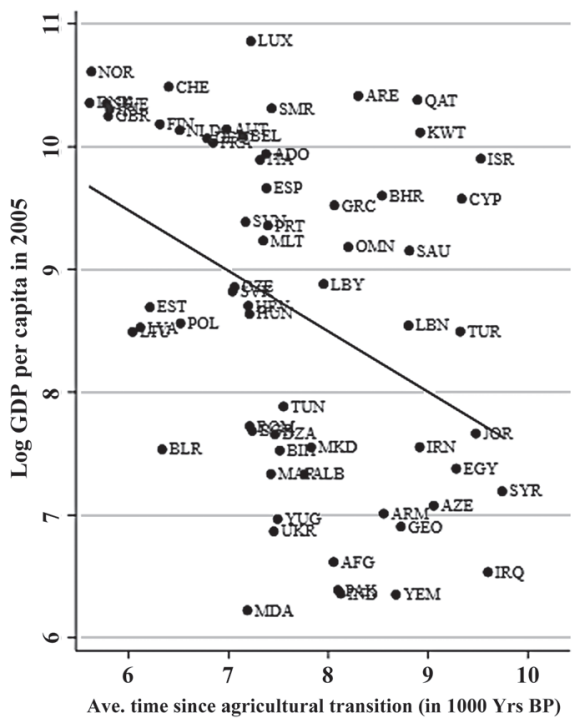

b) 257 Regions

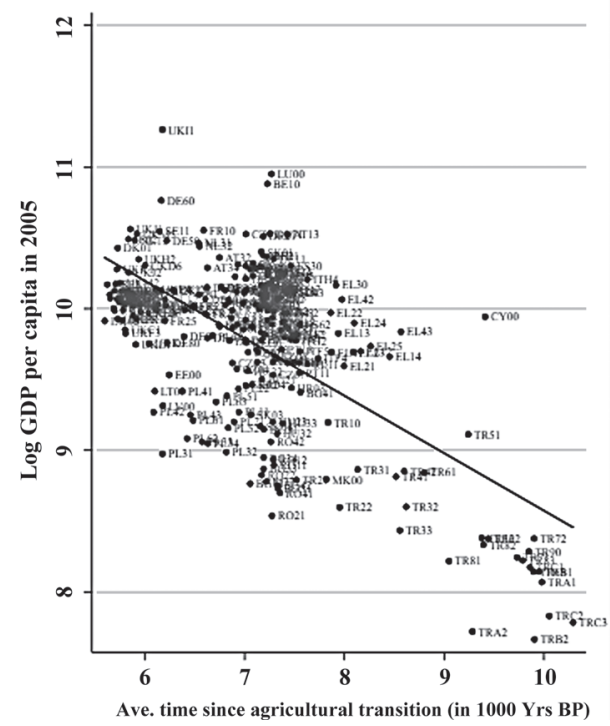

FIGURE 3

RELATIONSHIP BETWEEN LOG GDP PER CAPITA IN 2005

AND AVERAGE TIME SINCE AGRICULTURAL TRANSITION

AMONG (A) 64 WESTERN COUNTRIES AND (B) 257 NUTS2-REGIONS IN EUROPE

Notes: The figure shows the scatterplot and fitted line for the bivariate relationship between Log GDP per capita in 2005 and Average time since agricultural transition from the regression specification in Table 1.

Source: Own map based on data from Eurostat and Pinhasi, Fort, and Ammerman (2005).

that aside from the timing of transition, both log arable land area and log distance to coast and river remain consistently negative and statistically significant. These two geographic factors likely have direct impact on the outcome variable and remain important throughout different specifications, while other geographical controls, such as temperature, precipitation, area and altitude, roughness and terrain, and distance to Addis Abeba do not. ${ }^{9}$ In the following specifications, we therefore include the two variables as controls for geography.

In Tables 3 and 4, we present further robustness checks on our crosscountry results. First in Table 3, we vary the samples in our data to check whether the countries in the Fertile Crescent may be fundamentally different in some way and drive the results. In Column (1), we therefore include a Fertile Crescent-dummy and in Column (2) we exclude the

\footnotetext{
${ }^{9}$ Ashraf and Galor (2013) use Migratory distance from Addis Abeba as an instrumental variable for genetic diversity, which the authors also argue to contribute to economic development.
} 
TABLE 2

BASELINE CROSS-COUNTRY RESULTS CONTROLLING FOR GEOGRAPHY

\begin{tabular}{|c|c|c|c|c|c|c|c|}
\hline & (1) & (2) & (3) & (4) & (5) & (6) & (7) \\
\hline & \multicolumn{7}{|c|}{$\begin{array}{c}\text { Dependent Variable: } \\
\text { Log GDP per Capita in } 2005\end{array}$} \\
\hline $\begin{array}{l}\text { Average time since } \\
\text { agricultural transition }\end{array}$ & $\begin{array}{c}-0.492 * * * \\
(0.133)\end{array}$ & $\begin{array}{c}-0.469 * * \\
(0.198)\end{array}$ & $\begin{array}{c}-0.485^{* * *} \\
(0.121)\end{array}$ & $\begin{array}{c}-0.547 * * * \\
(0.134)\end{array}$ & $\begin{array}{c}-0.308^{* *} \\
(0.149)\end{array}$ & $\begin{array}{c}-0.347 * * \\
(0.150)\end{array}$ & $\begin{array}{c}-0.313^{* *} \\
(0.136)\end{array}$ \\
\hline \multicolumn{8}{|l|}{$\begin{array}{l}\text { Predicted time since } \\
\text { agricultural transition }\end{array}$} \\
\hline Conley SE & [0.189] & [0.194] & {$[0.138]$} & {$[0.151]$} & {$[0.147]$} & {$[0.179]$} & [0.139] \\
\hline Log latitude & & $\begin{array}{l}1.733 * * \\
(0.777)\end{array}$ & & & & & \\
\hline $\begin{array}{l}\text { Log land suitability for } \\
\text { agriculture }\end{array}$ & & $\begin{array}{c}0.078 \\
(0.188)\end{array}$ & & & & & \\
\hline Log arable land area & & $\begin{array}{c}-0.632 * * * \\
(0.223)\end{array}$ & $\begin{array}{c}-0.483^{* * *} \\
(0.120)\end{array}$ & $\begin{array}{c}-0.518 * * * \\
(0.136)\end{array}$ & $\begin{array}{c}-0.615^{* * *} \\
(0.135)\end{array}$ & $\begin{array}{c}-0.482 * * * \\
(0.129)\end{array}$ & $\begin{array}{c}-0.510^{* * *} \\
(0.106)\end{array}$ \\
\hline $\begin{array}{l}\text { Log distance to coast or } \\
\text { river }\end{array}$ & & & $\begin{array}{c}-0.663 * * * \\
(0.097)\end{array}$ & $\begin{array}{c}-0.625 * * * \\
(0.173)\end{array}$ & $\begin{array}{c}-0.653 * * * \\
(0.105)\end{array}$ & $\begin{array}{c}-0.689 * * * \\
(0.095)\end{array}$ & $\begin{array}{c}-0.582 * * * \\
(0.115)\end{array}$ \\
\hline Log mean altitude & & & & $\begin{array}{l}-0.146 \\
(0.231)\end{array}$ & & & \\
\hline Log area & & & & $\begin{array}{c}0.007 \\
(0.133)\end{array}$ & & & \\
\hline Roughness of terrain & & & & $\begin{array}{c}1.839 \\
(1.534)\end{array}$ & & & \\
\hline Temperature & & & & & $\begin{array}{l}-0.033 \\
(0.027)\end{array}$ & & \\
\hline Precipitation & & & & & $\begin{array}{c}0.006 \\
(0.007)\end{array}$ & & \\
\hline $\begin{array}{l}\text { Migratory distance to } \\
\text { Addis Abeba }\end{array}$ & & & & & & $\begin{array}{c}0.211 \\
(0.158)\end{array}$ & \\
\hline Longitude & & & & & & & $\begin{array}{c}-0.020 * * \\
(0.007)\end{array}$ \\
\hline Constant & $\begin{array}{c}12.435^{* * * *} \\
(0.984)\end{array}$ & $\begin{array}{l}7.429 * \\
(4.252) \\
\end{array}$ & $\begin{array}{c}16.650^{* * *} \\
(1.011)\end{array}$ & $\begin{array}{c}16.496^{* * *} \\
(1.604)\end{array}$ & $\begin{array}{c}15.722 * * * \\
(1.291)\end{array}$ & $\begin{array}{c}14.681 * * * \\
(1.795)\end{array}$ & $\begin{array}{c}15.542 * * * \\
(1.113) \\
\end{array}$ \\
\hline Observations & 64 & 55 & 59 & 59 & 59 & 59 & 59 \\
\hline R-squared & 0.16 & 0.41 & 0.52 & 0.54 & 0.55 & 0.54 & 0.57 \\
\hline
\end{tabular}

Notes: The estimator is OLS in all specifications. Robust standard errors are in parentheses. In calculating Conley standard errors (in square brackets), we assume that spatial autocorrelation exists among observations which are within ten degrees of each other. ${ }^{* *} \mathrm{p}<0.01,{ }^{* *} \mathrm{p}<0.05,{ }^{*} \mathrm{p}<0.1$. The sample is all countries specified as Western in the text with available data.

Source: See Online Appendix B for data sources. 


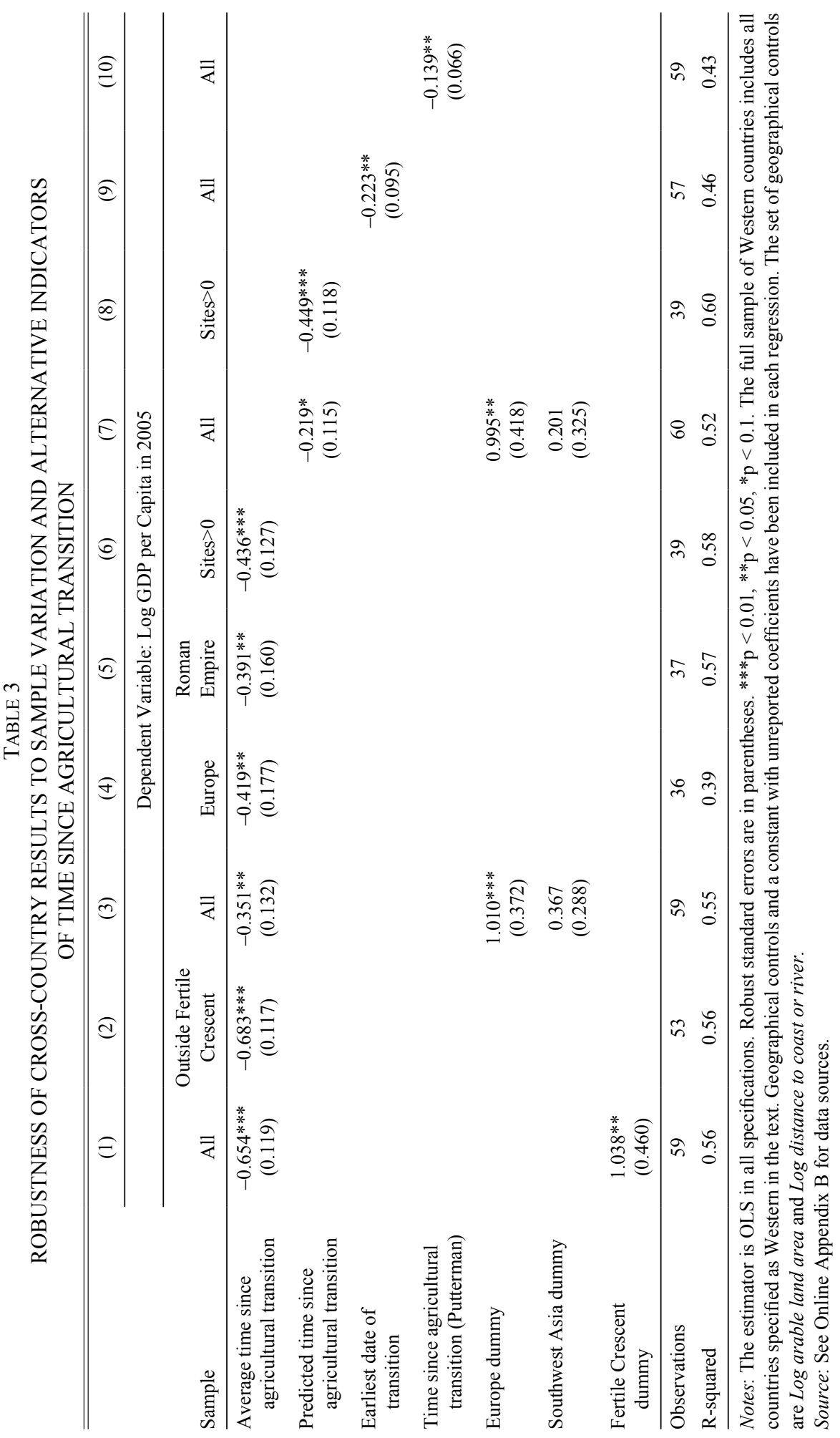




\section{TABLE 4 \\ CROSS-COUNTRY RESULTS CONTROLLING FOR VARIOUS HISTORICAL CHANNELS}

\begin{tabular}{|c|c|c|c|c|c|}
\hline & \multirow[b]{2}{*}{$\begin{array}{l}\text { Historical } \\
\text { Control Variable(s): }\end{array}$} & \multicolumn{4}{|c|}{ Dependent Variable: Log GDP per capita in 2005} \\
\hline & & $\begin{array}{c}\text { OLS Point } \\
\text { Estimate for } \\
\text { Historical Control }\end{array}$ & $\begin{array}{l}\text { OLS Point Estimate } \\
\text { for Average time since } \\
\text { agricultural transition }\end{array}$ & Obs. & $\mathrm{R} 2$ \\
\hline (1) & None & None & $\begin{array}{l}-0.485 * * * \\
(0.121)\end{array}$ & 59 & 0.52 \\
\hline (2) & $\begin{array}{l}\text { Predicted genetic diversity } \\
\text { Predicted genetic diversity sq. }\end{array}$ & $\begin{array}{c}-4,450.98 \\
3,002.40\end{array}$ & $\begin{array}{c}-0.426^{* * *} \\
(0.155)\end{array}$ & 59 & 0.56 \\
\hline (3) & Ethnic fractionalization & $-1.337 * *$ & $\begin{array}{c}-0.405^{* * *} \\
(0.113)\end{array}$ & 58 & 0.59 \\
\hline (4) & Atlantic dummy & $1.224 * * *$ & $\begin{array}{c}-0.282^{* *} \\
(0.133)\end{array}$ & 59 & 0.61 \\
\hline$(5 a)$ & State history $1-1950 \mathrm{CE}$ & $2.633 * * *$ & $\begin{array}{c}-0.539^{* * *} \\
(0.156)\end{array}$ & 50 & 0.57 \\
\hline$(5 b)$ & State history $1-1500 \mathrm{CE}$ & 1.414 & $\begin{array}{c}-0.583^{* * *} \\
(0.168)\end{array}$ & 50 & 0.51 \\
\hline \multirow[t]{5}{*}{ (6) } & Roman empire in $200 \mathrm{CE}$ & 0.346 & $-0.478^{* * *}$ & 59 & 0.67 \\
\hline & Byzantine empire in $500 \mathrm{CE}$ & 0.229 & $(0.154)$ & & \\
\hline & Carolingian empire in $800 \mathrm{CE}$ & $0.886^{* *}$ & & & \\
\hline & Mongol invasion in $1300 \mathrm{CE}$ & $-0.731 * * *$ & & & \\
\hline & Ottoman empire in $1600 \mathrm{CE}$ & -0.001 & & & \\
\hline \multirow[t]{3}{*}{ (7) } & Legal origin United Kingdom & $0.963^{* *}$ & $-0.458 * * *$ & 59 & 0.62 \\
\hline & Legal origin France & $0.708^{* *}$ & $(0.122)$ & & \\
\hline & Legal origin Scandinavia & $1.430 * * *$ & & & \\
\hline (8) & Crusades & $0.003 * * *$ & $\begin{array}{c}-0.464 * * * \\
(0.125)\end{array}$ & 59 & 0.54 \\
\hline (9) & Protestant population & $0.015 * * *$ & $\begin{array}{l}-0.266^{*} \\
(0.139)\end{array}$ & 58 & 0.59 \\
\hline
\end{tabular}

Notes: The estimator is OLS in all specifications. Each row presents results from a specific regression with historical controls as specified. Robust standard errors have been used in all specifications and are shown for the point estimates of Average time since agricultural transition, but are not reported for the historical variables. ${ }^{* *} \mathrm{p}<0.01,{ }^{*} \mathrm{p}<0.05,{ }^{*} \mathrm{p}<0.1$. The sample is all countries specified as Western in the text with available data. Geographical controls and a constant with unreported coefficients have been included in each regression. The geographical controls are Log arable land area and Log distance to coast or river.

Source: See Online Appendix B for data sources. 
Fertile Crescent countries altogether. The result of this exercise is that the estimate for Average time since agricultural transition becomes more negatively sloped and even more significant. In Column (3), we include two continental dummies for Europe and Southwest Asia. The Europe dummy is positive and significant, as one might expect. In Columns (4) and (5), we restrict the sample to only European and only former Roman countries, respectively. The latter countries arguably shared a similar institutional and cultural context during a very formative period of Western history. Even in these limited samples and when controlling for the standard geographical and historical variables, time since agricultural transition is still significant. In Column (6), we restrict the sample to only those countries with at least one Pinhasi site within their borders. The basic result stays the same.

Next, we replace Average time with three other measures: Predicted time since agricultural transition, Earliest date of transition, and Putterman's Time since agricultural transition. The first measure is based on the location and dating of the 765 sites in the Pinhasi, Fort, and Ammerman (2005) sample. We exploit the observed pattern of a fairly stable speed of agricultural diffusion across space from the area of origin in the Fertile Crescent. That is, the predicted time is a linear function of the distance between the archaeological site Jericho, considered as the origin of agricultural diffusion, and the center of each region. This measure explicitly considers the timing of agricultural adoption as an outcome of the region's location and its distance to Jericho, based on the demic diffusion theory. Earliest date uses information on the earliest incidence of agriculture within a country rather than the average date of transition. ${ }^{10}$ Although the estimates in (8)-(10) are closer to zero, the negative slope coefficients are significant in both cases.

Given that the diffusion process spread to hunter-gathering societies in one direction, rather than what one may consider as a process of cultural exchange, in this article we essentially interpret the transition as an exogenous shock to the region. But what if there were pre-existing cultural differences that sometimes influenced the transition date? Acemoglu and Robinson (2012), for instance, suggest that the Natufians, who lived in the Middle East during the Mesolithic period, perhaps had adopted a sedentary lifestyle as a more or less random technological innovation that had not so much to do with how suitable the wild plants and animals

\footnotetext{
${ }^{10}$ Online Appendix B describes in detail the formulas used for the alternative measure. It could be argued that the earliest date is more in line with the method used in Putterman (2006) whose data provide the basis for the empirical results in several papers.
} 
in the neighborhood were for domestication. A similar line of reasoning is also found in Bowles and Choi (2013), who argue that an institutional innovation of private property in certain societies sometimes preceded transition to agriculture. Although we recognize this possibility, we find no reason to believe that such variations were systematically related to the distance to Jericho to bias our empirical results.

Similarly, a key identifying assumption in this setup is further that the income level did not in any way influence timing of agricultural adoption. Although local geographical and climatic conditions no doubt played a role in the diffusion of agriculture, we can control for a set of these exogenous factors. In doing so we think there are no good reasons to believe that current or historical levels of income per capita should have any plausible reverse causality on the date of agricultural transition. ${ }^{11}$ The main reason for this is the widespread archaeological and genetic support for the "Neolithic demic diffusion model," arguing that agriculture mainly spread through physical migration by people from the original farming areas in the Fertile Crescent to areas in the periphery. ${ }^{12}$ Agriculture thus typically appeared in a region as an exogenous intervention and did not arise indigenously.

Finally in Table 4, we check the robustness of our main results to inclusion of a list of other historical variables that have been proposed as important in the literature, while also controlling for geography. The estimates of the historical variables are shown in the second column. ${ }^{13}$ The first variable that we try is Ashraf and Galor (2013)'s Predicted genetic diversity and Predicted genetic diversity squared. For the world as a whole, this variable was shown to have an inverted u-shaped relationship with income in the original study. In our Western sample, the estimates have the wrong sign and are not significant. Ethnic fractionalization in Row (3) is negative and significant, but so is the coefficient estimate for Average time since agricultural transition.

Perhaps our main variable capturing time since the Neolithic just happens to be correlated with historical Atlantic trade, which is the true

\footnotetext{
${ }^{11}$ One might imagine individual episodes whereby advancing farmers met resistance from particularly prosperous hunter-gatherers. Bellwood (2005) suggests, for instance, that the relatively late colonization of the areas surrounding the Baltic Sea might have been due to the very rich aquatic resources that the local inhabitants had access to. This implies that the distance to coast would be an important factor in explaining the lifestyle of these inhabitants. The marine resources would be an important part of the diet even after farmers had come to dominate the area.

${ }^{12}$ See Ammerman and Cavalli-Sforza (1984) and Bellwood (2005) for thorough accounts of this theory.

${ }^{13}$ For brevity, we have omitted reporting standard errors.
} 
driving force behind the rise of Western Europe, as hypothesized by Acemoglu, Johnson, and Robinson (2005)? In Row (4), we introduce an Atlantic dummy, which turns out to be strongly positive and significant. However, Average time since agricultural transition is still negative and significant. An indicator for the duration of state experience State history $1-1950$ is entered in Row (5a), and the duration of state experience from $1-1500$ is entered in Row (5b). Despite the strong link between time since the Neolithic and subsequent state history, up to and past European colonization, the control variables do not make the estimate of Average time since agricultural transition statistically insignificant. Hence, the long-term impact of agriculture does not appear to run solely through the timing of state formation.

In Row (6), we include a whole set of historical empire proxies capturing the proportion of the country controlled by Roman, Byzantine, Carolingian, and Ottoman rulers, as well as a dummy for whether the country was overrun by Mongols in 1300 CE. ${ }^{14}$ Having been included in the Carolingian empire had a clear positive influence while Mongolian rule had a negative impact, but our main coefficient of interest is almost unaffected. Furthermore, the Legal Origin indicators in Row (7), often included as important determinants of economic performance (La Porta, Lopez-De-Silanes, and Shleifer 1999) are all significant, but do not seem to be very important mediator variables.

One potential mediator variable that may explain divergence of development in Europe especially between 1000 and 1500 CE may be the rise of Holy Land Crusades. Blaydes and Paik (2016), for example, document that the areas with larger numbers of crusaders subsequently witnessed increased political stability, urbanization, and institutional development. From their work, we use the number of Crusade location points in each country across the four waves of recruitment, with the First Crusades beginning in 1096 and the Fourth Crusades ending in 1204. These were the "largest and most significant of the Crusades. Indeed, out of 1,051 elite crusaders... 916 are categorized as participating in the first four waves" (Blaydes and Paik 2016, pp. 566-67). Row (8) includes the number of Crusade recruitment locations from Blaydes and Paik (2016) as a proxy for Crusader presence. When we control for the Crusades (which appears to have a positive impact on the current income level), we still find the agricultural adoption variable to be statistically significant and negative.

\footnotetext{
${ }^{14}$ We have coded the latter Mongol variable ourselves. A description for the coding procedure is available upon request.
} 
Another related factor in our historical framework is religion. All the old areas of civilization are currently dominated by Muslims whereas Protestants are the majority in northern Europe. Furthermore, important scholarly works argue that certain institutional features of Islam were harmful to economic development whereas the Protestant emphasis on individualism has been discussed as a beneficial factor for economic development at least since Max Weber. ${ }^{15}$ When we control for the Protestant population percentages in Row (9), the estimate for Average time since agricultural transition remains significant.

Finally, an additional historical shock which has been emphasized by many authors is the Black Death of 1347-1353 CE (Clark 2008; Voigtländer and Voth 2013). Could it have been an extra high mortality in Black Death that "shocked" the north European countries and regions into a new equilibrium with higher wages and higher urbanization? Any such analysis is plagued by the fact that cross-country data on mortality from the Black Death are generally very unreliable. In Figure $\mathrm{C} 1$ of Online Appendix, we show the relationship between Average time since agricultural transition and Black Death mortality among 53 Western cities, using data from Christakos et al. (2005). Interestingly, the relationship in the figure is positive, indicating that the cities with a long history of agriculture were actually worse hit by the Black Death on average. Although this evidence is far from conclusive, it does not seem to give support to a reversal happening because of a more adverse shock in north Europe. ${ }^{16}$ In summary, we show that our main variable is robust to the inclusion of a range of historical variables suggested in the literature.

In addition to the series of robustness checks noted earlier, we evaluate whether our key findings are robust to changing the level of aggregation. Table 1, Column (2) shows the results for the cross-regional analysis, among the intrastate regions in 29 countries. Figure 3, Panel (b) shows an unconditional bivariate scatter plot for 257 NUTS2 intra-state regions with available data. The table again shows that the negative relationship persists at the finer regional level. The estimate for Average time since

\footnotetext{
${ }^{15}$ See, for instance, Kuran (2010) for an in-depth account of how Islam affected economic development in the Western core and Landes (1998) for a treatment of Protestantism.

${ }^{16}$ An alternative hypothesis, advanced by Borsch (2005), is that although Western countries often experienced fairly similar shocks in terms of mortality rates, it was pre-existing institutional differences between collectivist and absolutist countries such as Egypt and more individualoriented countries such as England, which determined the response to the Black Death. In Mamluk Egypt, coercion became even worse as a result of the plague, whereas rising wages due to labor shortage gave workers in England stronger social positions than before. One might thus view the Black Death as a key event for the emergence of the reversal, whereby the importance of existing institutional differences, caused in turn by the different agricultural histories, was magnified and pushed northwestern Europe into a take-off.
} 
TABLE 5

CROSS-REGIONAL ANALYSIS AMONG 285 EUROPEAN NUTS2-REGIONS

\begin{tabular}{lcccc}
\hline \hline & $(1)$ & $(2)$ & $(3)$ & $(4)$ \\
\cline { 2 - 5 } & \multicolumn{5}{c}{ Dependent Variable: } \\
& \multicolumn{5}{c}{ Log GDP per Capita in 2010 } \\
\hline Average time since & $-0.406^{* * *}$ & $-0.420^{* * *}$ & $-0.188^{* * *}$ & $-0.188^{* * *}$ \\
agricultural transition & $(0.032)$ & $(0.030)$ & $(0.052)$ & $(0.050)$ \\
Conley SE & {$[0.074]$} & {$[0.075]$} & {$[0.088]$} & {$[0.079]$} \\
Constant & $12.362^{* * *}$ & $12.758^{* * *}$ & $11.213^{* * *}$ & $11.064^{* * *}$ \\
& $(0.219)$ & $(0.200)$ & $(0.303)$ & $(0.301)$ \\
Geographical controls & No & Yes & No & Yes \\
Country FE & No & No & Yes & Yes \\
\hline Observations & 283 & 277 & 283 & 283 \\
R-squared & 0.41 & 0.43 & 0.84 & 0.84 \\
\hline
\end{tabular}

Notes: The estimator is OLS. Columns (3) and (4) include country fixed effects. The sample is all Western regions with available data on NUTS2-level. Robust standard errors are in parentheses. $* * * \mathrm{p}<0.01, * * \mathrm{p}<0.05, * \mathrm{p}<0.1$. In calculating Conley standard errors (in square brackets) for the estimates of Average time since agricultural transition, we assume that spatial autocorrelation exists among observations which are within ten degrees of each other. The controls are fraction of land suitable for agriculture and log distance to coast or river.

Source: See Online Appendix B for data sources.

agricultural transition is negative and significant even when we control for country fixed effects and focus on within-country variations. Table 5 presents the results, in which the slope coefficient changes but retains its significance. With both geography and country fixed effects, $R^{2}$ is 0.76 (Table 5, Column 4), which indicates that our specification explains a quite large proportion of the variation in regional income levels.

In order to zoom in even more closely on a micro level, we also use data for time since transition and average levels of GDP per capita that we have collected on the NUTS3-level of aggregation. Table 6 presents the results for five of the largest countries in the sample with many Pinhasi sites within their borders (Germany, France, Italy, Spain, and Turkey), in which we find that there remains the overall negative relationship within countries except in Germany where there is a positive relationship. In Figure $4 \mathrm{a}$, we show the combined unconditional bivariate scatter plot between the income measure and average time since agricultural transition for 1,371 Western NUTS3 regions. Figure $4 \mathrm{~b}$ shows separate unconditional regression lines for Germany, France, Italy, Spain, and Turkey. The estimated slope coefficients for the whole sample is -0.484 , which is statistically significant at the 0.01 level. These results demonstrate a 
TABLE 6

WITHIN-COUNTRY RELATIONSHIPS BETWEEN AVERAGE GDP PER CAPITA

AND TIME SINCE AGRICULTURAL TRANSITION

FOR NUTS3-REGIONS IN FIVE LARGE COUNTRIES

DV: Log GDP per Capita 2005

\begin{tabular}{lc}
\hline Country & Average Time Since Agricultural Transition \\
\hline France (Obs.: 96) & $-0.184^{* *}$ \\
& $(0.016)$ \\
Germany (Obs.: 429) & $0.165^{* * *}$ \\
& $(0.037)$ \\
Italy (Obs.: 107) & $-0.533^{* * *}$ \\
& $(0.104)$ \\
Spain (Obs.: 51) & $-0.773^{* * *}$ \\
& $(0.168)$ \\
Turkey (Obs.: 81$)$ & $-0.323^{* * *}$ \\
& $(0.033)$ \\
\hline
\end{tabular}

Notes: The table shows estimated coefficients for the within-country relationships between agricultural transition dates and log average GDP per capita 2005 for the five largest countries. The estimator is OLS in all specifications and each observation is a NUTS3-region. A constant with unreported coefficients has been included in all regressions. Robust standard errors are in ()-parentheses. Pinhasi sites refers to the number of archaeological sites in Pinhasi, Fort, and Ammerma (2005) within each country's borders that are used to assess the date of transition for each region. $* * * p<0.01, * * p<0.05, * \mathrm{p}<0.1$.

Source: See Online Appendix B for data sources.

strong negative relationship between the timing of agricultural transition and GDP per capita both across and within most countries. The strong negative correlations at a disaggregated level within countries like Turkey, Spain, and Italy are particularly striking. ${ }^{17}$

\section{Timing of the Reversal}

When did this reversal happen in the Western world? The Industrial Revolution, starting around 1800, contributed to the economic and technological dominance of Britain and other north European countries (Mokyr 1990; Acemoglu and Robinson 2012). Before the Revolution, the great divergence in the Western world after $1500 \mathrm{CE}$ was due in part to the opening of the Atlantic trade and colonial ventures (Acemoglu, Johnson,

17 The individual estimates for these countries with controls are further shown in Table $\mathrm{C} 1$ in Online Appendix. The intrastate results are however weaker than at the state-level; the unconditional regression coefficient for Germany, for example, is positive and significant, and suggests that strong modern state institutions (i.e., West vs. East Germany divide) may neutralize much of within-state variations in GDP per capita. 


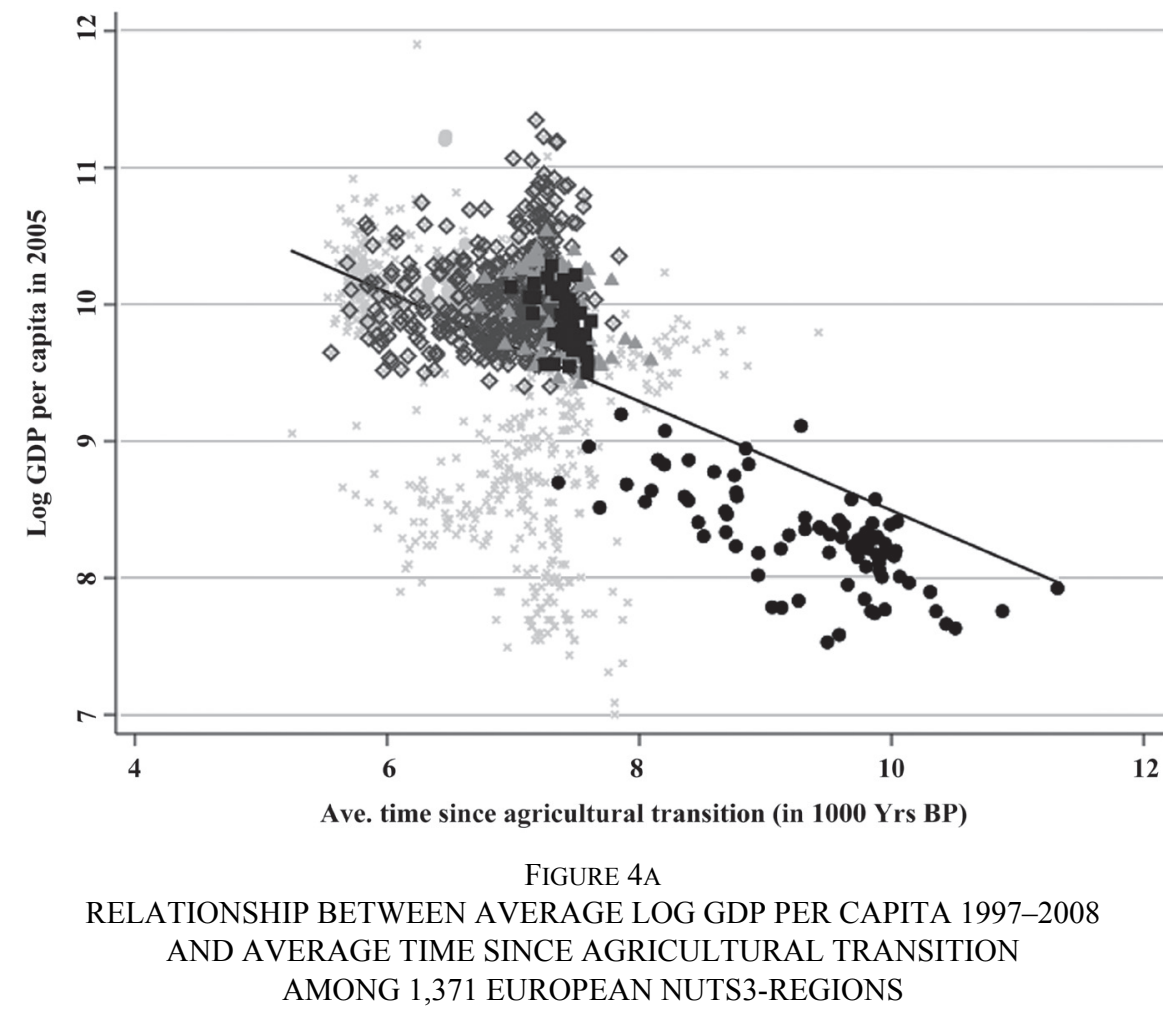

Notes: The figure shows the scatter plot and fitted regression line for the bivariate relationship between Average Log GDP per capita 1997-2008 and Average time since agricultural transition (in $\mathrm{k}$ years) for 1,371 Western NUTS3-regions. It also shows the distinct scatter plots for Germany, France, Italy, Spain, and Turkey. German observations are hollow diamonds, French observations grey circles, Italian observations light triangles, Spanish observations squares, and Turkish observations black circles. All other region observations are black. More details for the within-country regressions are shown in Table 2 . The estimated coefficients for region $\mathrm{i}$ in country $\mathrm{j}$ are (with robust standard errors in parenthesis): Average log GDP per capita 1997-2008 $(i j)=$ $12.99(0.147)-0.484(0.021) *$ Average time since agricultural transition $(i j)+\varepsilon(i j)$.

Source: Own map based on data from Eurostat and Pinhasi, Fort, and Ammerman (2005).

and Robinson 2005). Some scholars trace the root of Western Europe's rise to pre-1500 CE. Putnam, Leonardi, and Nanetti (1993), for example, trace the differences in current institutional performance in Italy back to 1100 CE's governance structure and social networks. Voigtländer and Voth (2013) discuss the Black Death of 1347 CE, which shocked many parts of Europe into a new pattern of rising wages and higher urbanization rates that further sped up susceptibility to plagues and a greater fiscal capacity. Bosker, Buringh, and Van Zanden (2013)'s city-level analysis of the Western zone shows that the faster growth of the European cities compared to Islamic cities during the Medieval period can be partly attributed to the more democratic and republican traditions in Europe, especially in Italy 

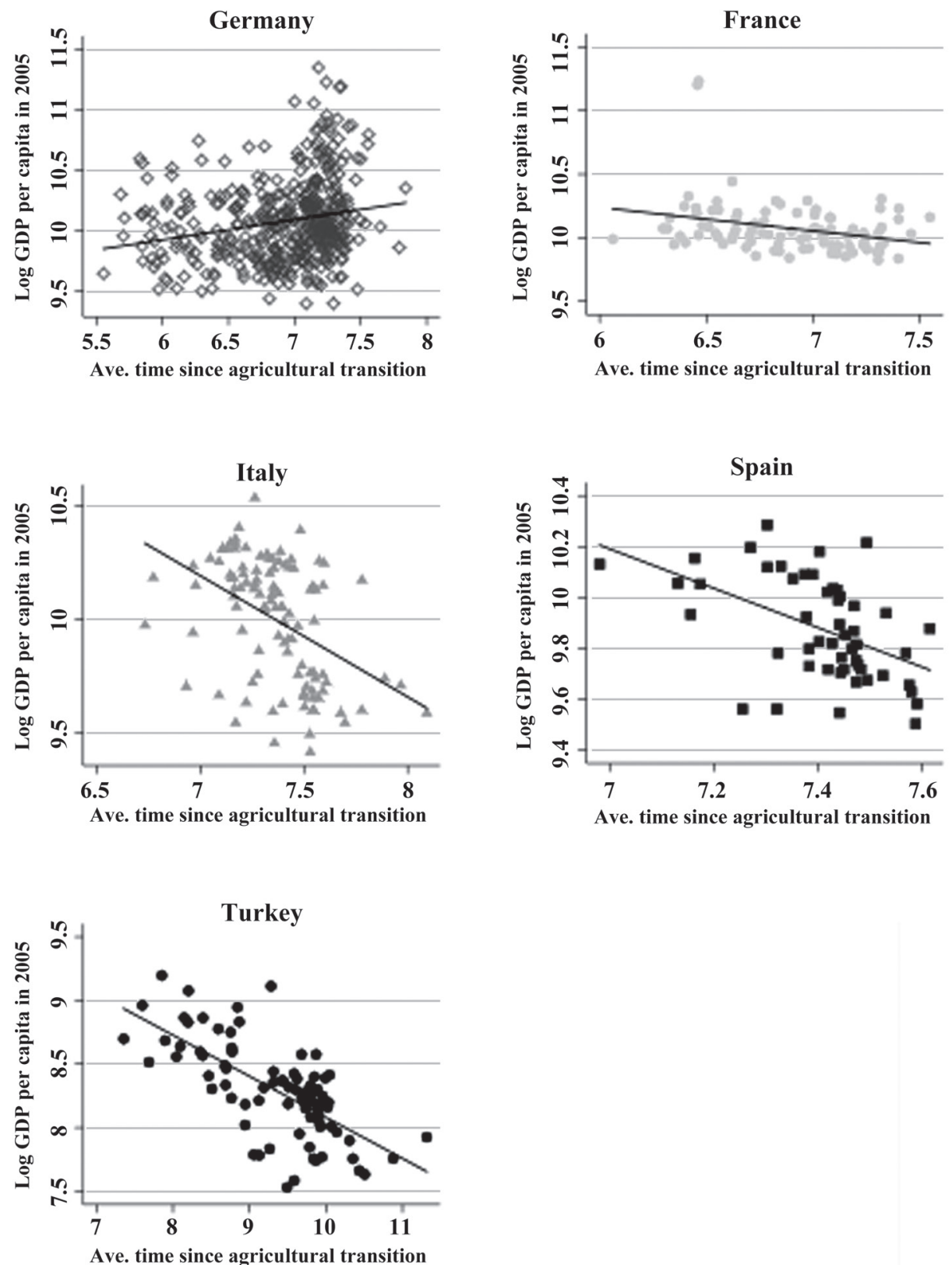

FIGURE 4B

BIVARIATE RELATIONSHIPS BETWEEN AVERAGE LOG GDP PER CAPITA 2005 AND AVERAGE TIME SINCE AGRICULTURAL TRANSITION AMONG THE SIX LARGEST COUNTRIES IN WESTERN ZONE

Notes: The figures show the bivariate, unconditional relationships between average log GDP per capita in 2005 and average time since agricultural transition among NUTS3-regions within the five largest countries in the Western zone: Germany, France, Italy, Spain, and Turkey.

Source: Own map based on data from Eurostat and Pinhasi, Fort, and Ammerman (2005). 
TABLE 7

HISTORICAL EVOLUTION OF RELATIONSHIP

\begin{tabular}{lccccc}
\hline \hline & \multicolumn{5}{c}{$\mathrm{DV}:$} \\
\cline { 2 - 6 } & \multicolumn{4}{c}{ Log Population Density in: } & \multicolumn{2}{c}{ Log GDP per Capita in: } \\
\cline { 2 - 7 } & $1 \mathrm{CE}$ & $1000 \mathrm{CE}$ & $1500 \mathrm{CE}$ & $1500 \mathrm{CE}$ & $1820 \mathrm{CE}$ \\
\hline Average time since agricultural & 0.215 & -0.001 & $-0.231^{*}$ & $-0.050^{*}$ & $-0.180^{* * *}$ \\
transition & $0.142)$ & $(0.125)$ & $(0.137)$ & $(0.024)$ & $(0.033)$ \\
Observations & 54 & 60 & 61 & 21 & 28 \\
\hline
\end{tabular}

Notes: The estimator is OLS in all specifications. Average time since agricultural transition is measured as time since the transition at the corresponding date of the dependent variable (i.e., $1 \mathrm{CE}, 1000 \mathrm{CE}$, etc.). Robust standard errors in parenthesis. $* * * p<0.01,{ }^{* *} \mathrm{p}<0.05,{ }^{*} \mathrm{p}<0.1$. The sample is always all Western countries with available data. A constant with unreported coefficients have been included in each regression.

Source: See Online Appendix B for data sources.

and Flanders. Blaydes and Chaney (2013) focus on ruler duration and find that European durations were longer than in the Islamic world by $900 \mathrm{CE}$, due to the feudal system that decentralized power in Europe and gave rise to greater political stability and more beneficial economic development.

A key question in our analysis is whether the reversal since the Neolithic was visible already during the First Great Divergence, 1500-1800 CE. For the Malthusian era, it is widely accepted that population density is a better indicator than GDP per capita for the level of economic development in a country (Ashraf and Galor 2011). In Table 7 Columns (1)-(3), we use logged population density in years 1,1000 , and $1500 \mathrm{CE}$ as dependent variables. In $1 \mathrm{CE}$, the reversal does not seem to be in place since the estimate for Average time since agricultural transition is positive. In $1000 \mathrm{CE}$, the estimate is negative but insignificant. However, by $1500 \mathrm{CE}$, the reversal is evident; the time since agricultural transition in that year is both negative and significant. In Columns (4) and (5), we instead use Log GDP per capita from 1500 and $1820 \mathrm{CE}$ as the dependent variables. The estimate for Average time since agricultural transition is negative in $1500 \mathrm{CE}$ and becomes strongly significant as time passes. When we use income per capita data also for years 1000, 1600, 1700, 1913, 1980, and 2005 CE and run the same regressions as in Table 7, we can track more in detail how the regression coefficient of Average time since agricultural transition develops over time. Figure 5 shows the patterns, suggesting an increasingly strong tendency for a reversal over the course of the millennium.

We do not interpret these results as evidence against the critical roles played by other historical channels explored in the literature. Undoubtedly, these fundamental processes contributed importantly to the great divergence that made Britain and its northern followers much 


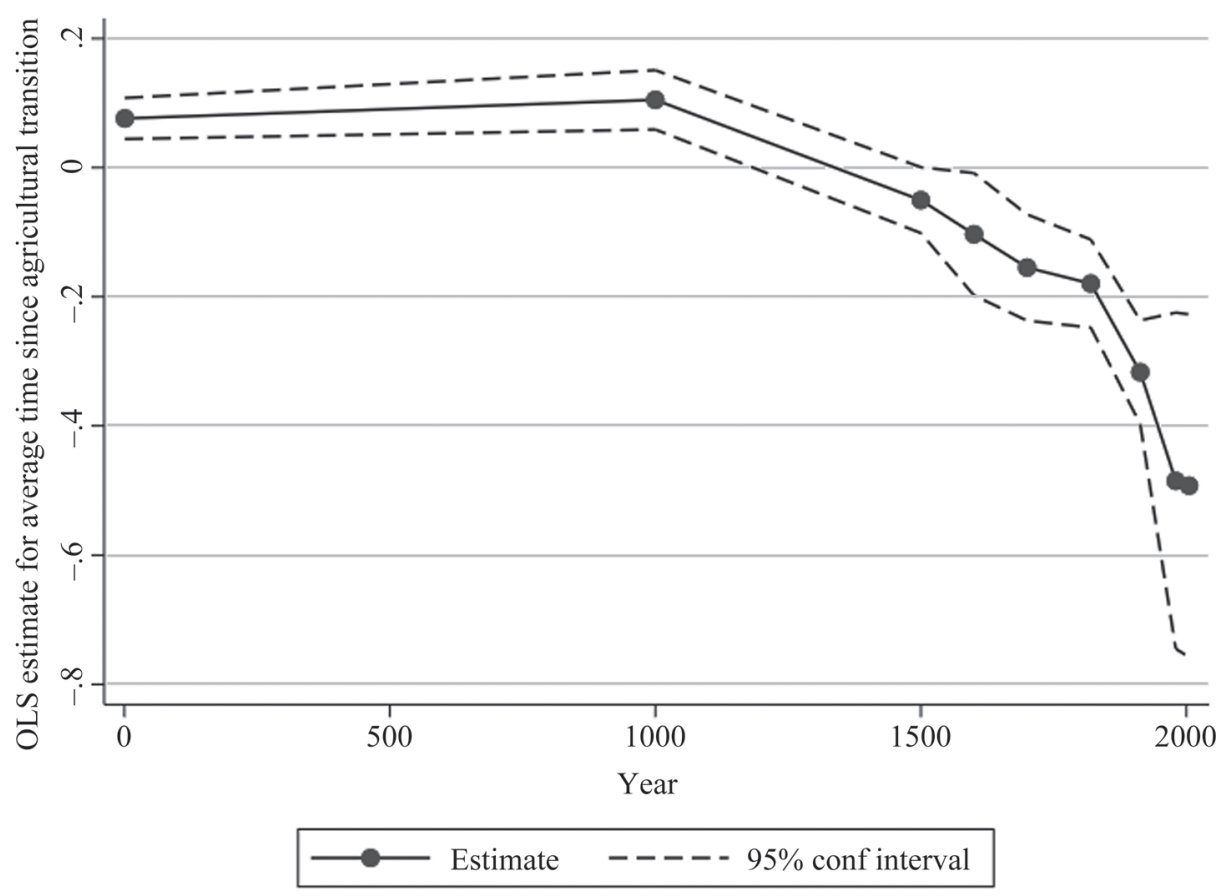

\section{FIGURE 5}

HISTORICAL EVOLUTION OF RELATIONSHIP BETWEEN LOG GDP PER CAPITA AND AVERAGE TIME SINCE AGRICULTURAL TRANSITION

\section{AMONG WESTERN COUNTRIES 1-2005 CE}

Notes: The figure shows the regression coefficients from eight separate regressions for different time periods, exploring the bivariate, unconditional relationships between average log GDP per capita and average time since agricultural transition. The eight $\beta_{1}$-estimates from these regressions are shown as grey circles, and the dashed lines represent the associated 95-percent confidence intervals. The included years $t$ (in the CE period with the number of Western country observations in parenthesis) are 1000 (20), 1500 (21), 1600 (19), 1700 (21), 1820 (28), 1913 (34), 1980 (43), and 2005 (64). Results from the regressions with controls for 1500 and 1820 are shown in Table 3 and for 2005 in Table 1. Results from the regressions for 1600, 1700, 1913, and 1980 are available upon request. Source: See Online Appendix B for data sources.

richer than the Mediterranean and Middle Eastern countries. What we do suggest, however, is that the process of reversing fortunes in the Western world seems to have followed an older trajectory, rooted in the transition to agriculture, which seems to have become manifested already by 1500 and has previously not been recognized.

\section{Democracy as an Intermediate Channel}

Do countries that made a late transition to agriculture over time develop more democratic institutions than early adopters? We find that agricultural adoption timing and indicators of inclusive, democratic institutions indeed have a strong association. In Table 8, we employ Democracy stock 
TABLE 8

INCLUSIVE INSTITUTIONS

\begin{tabular}{lcc}
\hline \hline & \multicolumn{2}{c}{$(1)$} \\
\hline & \multicolumn{2}{c}{ DV: } \\
\cline { 2 - 3 } & Democracy Stock & Executive Constraint \\
& $1900-2000$ & in 1500 \\
\hline Average time since agricultural transition & $-155.350^{* * *}$ & $-0.260^{* * *}$ \\
& $(39.048)$ & $(0.055)$ \\
Observations & 64 & 47 \\
\hline
\end{tabular}

Notes: Robust standard errors in parentheses. ${ }^{* * *} \mathrm{p}<0.01,{ }^{* *} \mathrm{p}<0.05,{ }^{*} \mathrm{p}<0.1$. The estimator is OLS in all specifications. The sample is always all Western countries with available data. A constant with unreported coefficients have been included in each regression.

Source: See Online Appendix B for data sources.

1900-2000 from Gerring et al. (2005). As described in Online Appendix B1, the authors use the sums of time-discounted individual country-year scores for the standard Polity2-variable over the 1900-2000 period, where Polity ${ }_{i, s}$ ranges in value from +10 (full democracy) to -10 (full autocracy) for country $i$ and year $s$. The highest scorer in our Western sample is Switzerland at 637 (full democracy throughout the period) and the lowest is Saudi Arabia at -604.6 . The variable might thus be said to measure an accumulated stock of democracy during the twentieth century. Our aim here is again not to establish a causal argument from institutions to economic performance, but to simply show that both of these endogenous outcomes are likely affected by our agricultural transition measure, and that the direction of effect on these two is the same.

Democracy stock 1900-2000 is the dependent variable in Column (1). We find that Average time since agricultural transition strongly predicts the level of the democracy stock such that countries with an early transition tended to be more autocratic during the twentieth century. The estimate is strongly significant both with and without geographical controls. It also implies that an earlier transition to agriculture by 1,000 years is associated with a 155.4 units lower democracy stock.

Column (2) presents a proxy for the level of executive constraints in 1500. The variable is mainly taken from Acemoglu, Johnson, and Robinson (2005), but is complemented with information for the Ottoman countries during the period. A high score indicates stronger constraints against the executive (and hence more inclusive institutions). In line with our hypothesis, Column (2) confirms that there indeed appears to be a strong relationship between the timing of the agricultural transition and Executive constraints in 1500 such that countries that adopted agriculture early had less inclusive institutions already by 1500 . 


\section{CONCEPTUAL FRAMEWORK: A DEVELOPMENT REVERSAL SINCE THE NEOLITHIC}

In this section, we present a conceptual framework to explain the key findings in the empirical section concerning a development reversal since the Neolithic in Western Eurasia. We start by introducing a formal growth theoretical model and then discuss how the model fits our findings, as well as those from the literature more generally.

\section{Key Assumptions}

Our model is in many ways a standard micro-founded Malthusian growth model over the very long run. The fundamental novel assumption that we introduce is that the dynamics of long-run total factor productivity in each country, over several millennia, follows a logistic growth pattern, characterized by four basic stages; a pre-agricultural (huntergatherer) stage, an early take-off stage soon after the transition to agriculture, a maturity stage after the emergence of states where productivity shifts from increasing to decreasing growth, and a stagnation phase where productivity levels have converged to levels close to the long-run maximum productivity potential of country $j .{ }^{18}$

There are two key premises that play a very important role for the pattern of productivity development: (i) The biogeographic potential of the natural environment for agriculture determines the timing of the adoption of Neolithic farming. The regions with the greatest potential will adopt sedentary agriculture first and enter an early take-off stage with rapid social development (Diamond 1997; Olsson and Hibbs 2005). (ii) The maximum productivity potential that is reached in the stagnation phase is lower in earlier adopting countries than in countries that adopt agriculture later. This implies that although late adopters will be far behind the productivity levels of early adopters early in history, the late adopters of agriculture and state organization will eventually overtake the early adopters when the

18 Our assumption of a logistic long-run development curve with associated basic stages, including a "take-off" and a "maturity" stage, goes back to Rostow (1960). However, in Rostow's account, the "traditional" stage included both hunting-gathering as well as subsistence agriculture up until the Industrial revolution. In our model, we emphasize instead the transition to Neolithic agriculture and the subsequent development of states, as a fundamental "game changer" in history that transformed societies. A logistic growth curve has also been used in numerous other applications in, for instance, biology, medicine, and innovation studies, to describe different phenomena. Our account is most similar to Borcan Olsson, and Putterman (2018), who also argue that long-run logistic curves can be used to describe the impact of state history on economic development. In the model, we integrate the transition to agriculture as a necessary and fundamental pre-condition for states and formalize a logistic productivity curve in a full economic growth model. 
latter have reached their lower stagnation phase (see a similar dynamics model in Lagerlöf (2016)). For this reason, the cross-country relationship between levels of development and time since transition to agriculture will be positive in early history and negative in later history.

We start by outlining the details of the model and then confront the assumptions and the predictions of the model with the results from our empirical section, as well as from existing research on long-run macro history in western Eurasia.

\section{Utility and the Intertemporal Budget Constraint}

Given the very long-run time frame considered in this research, the model is mainly intended to capture conditions during pre-industrial times when capital accumulation is relatively insignificant and when growth and income levels primarily depend on land, population levels, and total factor productivity.

A representative individual $i$ with an infinite life receives utility from consumption $C_{i t}$ of food and other basic commodities at a level above minimum subsistence level $\bar{c}$ :

$$
U_{i}=\sum_{t=0}^{\infty} \frac{u_{i}\left(c_{i t}-\bar{c}\right)}{(1+\rho)^{t}}
$$

where $\rho>0$ is a standard time discount rate. For any level of consumption above subsistence level, we assume the usual properties of a concave utility function: $u_{i}^{\prime}\left(c_{i t}-\bar{c}\right)>0$ and $u_{i}^{\prime \prime}\left(c_{i t}-\bar{c}\right)<0$. For all levels $c_{i t} \leq \bar{c}$, $\left(c_{i t}-\bar{c}\right)=0$.

The individuals' intertemporal budget restriction is given by

$$
\sum_{t=0}^{\infty} \frac{c_{i t}}{(1+r)^{t}} \leq \sum_{t=0}^{\infty} \frac{y_{i t}}{(1+r)^{t}},
$$

where $y_{i t}$ is the level of individual output, which we assume is equal to output per capita in the population as a whole, and $r>0$ are returns to savings from one period to the next. The standard Euler equation for an infinitely-lived individual that optimizes utility, given the intertemporal budget constraint, is

$$
\frac{u_{i}^{\prime}\left(c_{i t}-\bar{c}\right)}{u_{i}^{\prime}\left(c_{i t+1}-\bar{c}\right)}=\frac{1+r}{1+\rho} .
$$

In the long term, it is generally assumed that the time discount rate should be equal to the interest rate, that is, $r=\rho$. If that is the case, we should have perfect consumption smoothing so that the optimal level of consumption at each $t$ is $c_{t}^{*}=c_{t+1}^{*}=\cdots=c^{*}$. 


\section{Production}

Let us describe the total output produced in some country or region $j$ at time $t$ as

$$
Y_{j t}=A_{j t} X_{j}^{\alpha} L_{j t}^{1-\alpha},
$$

where $Y_{j t}$ is total output, $A_{j t}$ is total factor productivity, $X_{j}$ is the fixed amount of land, $L_{i j}$ is the level of the population, and $\alpha<1$ is the output elasticity of land. Output per capita is

$$
y_{j t}=\frac{A_{j t} X_{j}^{\alpha} L_{j t}^{1-\alpha}}{L_{j t}}=\frac{A_{j t}}{p_{j t}^{\alpha}},
$$

where $p_{j t}=L_{j t} / X_{j}$ is population density per unit of land.

\section{Malthusian Population Density and Consumption}

During most of the pre-industrial era, levels of population have adjusted to income per capita in a Malthusian fashion and grown such that income per capita has remained just above subsistence level $\bar{y}+\omega$ where $\bar{y}$ is the level of production associated with the minimum consumption level for survival $\bar{c}$ and $\omega>0$ is a small number reflecting a certain precaution among households in their fertility choice. Hence, we can show that the equilibrium population density must be

$$
p_{j t}^{*}=\left(\frac{A_{j t}}{\bar{y}+\omega}\right)^{\alpha} .
$$

Countries or regions will thus not differ in their levels of income per capita during these Malthusian times, but will have different levels of population density, depending on $A_{j t}$.

Inserting $c_{i t}=c^{*}, r=\rho$ and $y_{j t}=\bar{y}+\omega$ into the intertemporal budget restriction shows that

$$
\sum_{t=0}^{\infty} \frac{c^{*}}{(1+\rho)^{t}}=\frac{c^{*}}{\rho}=\sum_{t=0}^{\infty} \frac{y_{i t}}{(1+\rho)^{t}}=\frac{\bar{y}+\omega^{*}}{\rho},
$$

implying the standard Malthusian result that

$$
c^{*}=\bar{y}+\omega>\bar{c} .
$$


Hence, during the Malthusian era, productivity increases led to a great increase in total production and in population density, whereas output and consumption per capita remained close to subsistence level. ${ }^{19}$

\section{Total Factor Productivity}

So far, the model presented earlier has been a standard Malthusian growth model. We now introduce a novel modelling of long-term dynamics of total factor productivity (TFP). The account is a formalized version of the graphical analysis in Borcan, Olsson, and Putterman (2018) where the key assumption is that total long-term TFP $A_{j t}$ can be described as a logistic function, which we define mathematically here as:

$$
A_{j t}=\left\{\begin{array}{c}
\frac{\tilde{A}_{j}}{1+\left(\frac{\tilde{A}_{j}-A_{j \tau_{j}}}{A_{j \tau_{j}}}\right) e^{-g\left(t-\tau_{j}\right)}} \quad \text { if } t \geq \tau_{j} \\
1 \text { if } t<\tau_{j}
\end{array}\right.
$$

In this expression, $\tilde{A}_{j}$ is the long-run maximum productivity potential of country or region $j, \tau_{j} \in \boldsymbol{T}$ is the date when the population in country $j$ made the transition to Neolithic agriculture where $\boldsymbol{T}=\{0,1, t \ldots \infty\}$ is the set of all possible dates in time and $g>0$ is a productivity growth rate parameter. At all dates before the transition to agriculture $t<\tau_{j}$, we assume a pre-agricultural (hunter-gatherer) level of productivity of $A_{j t}=$ 1 for all $j$.

The growth of TFP in Equation (1) after the transition to agriculture is:

$$
\frac{\partial A_{j t}}{\partial t}=\dot{A}_{j t}=g A_{j t}\left(1-\frac{A_{j t}}{\tilde{A}_{j}}\right)
$$

The dynamics of TFP is thus such that the effective growth rate is $g\left(1-A_{j t} / \tilde{A}_{j}\right)$ right after the transition and then converges towards zero as $t \rightarrow \infty$. It is also the case that the expression in Equation (2) will be convex in the segment $A_{j t}<\tilde{A}_{j} / 2$ and concave thereafter, as the defining characteristic of a logistic function. More intuitively, the functional form

${ }^{19}$ However, when the Malthusian link between fertility and output levels finally started to break up after $1500 \mathrm{CE}$ in the Western area that we study, a higher productivity level would also be reflected in a higher income per capita. 
implies that there is a period of rapid and increasing productivity growth in what we refer to as a "take-off" stage, soon after the transition, a "maturity stage" where productivity shifts from increasing to decreasing growth, and then a "stagnation phase" when the productivity level has almost converged to its maximum potential $\tilde{A}_{j}$.

Countries and regions make the transition to agriculture at different dates $\tau_{j}$ where the sequence is such that $\tau_{1}<\tau_{2}<\ldots \tau_{J}$, and where $J$ is the last country in the (Western) geographical zone in the finite set of $\boldsymbol{J}$ existing countries. In line with Diamond (1997), Olsson and Hibbs (2005), and others, we make the assumption that $\tau_{1}\left(F_{1}\right)$, that is, the transition date of the origin region of agriculture in the zone, is a negative function of the quality of biogeographical conditions for agriculture $F_{1}$ such that $\tau_{1}^{\prime}\left(F_{1}\right)<0$. This implies that the country with the best endowment for agriculture in a geographical zone, having a large number of suitable plants and animals for domestication (like Mesopotamia in the Western zone or China in East Asia), will make the transition first. Agriculture then spreads through migration to the neighboring countries and regions, which typically have similar biogeographies.

After the transition, the economy enters a take-off stage where the benefits of the technological paradigm shift become manifest. More and more domesticated plants and animals are brought under human control, people settle in villages near commonly-held fields, orchards, irrigation structures, public buildings, and defensive fortifications. The early farming villages soon develop into complex and stratified social units capable of providing large-scale public goods that further enhance productivity in food production (Scott 2017). Eventually, centralized states with kings, soldiers, and bureaucrats emerge as the elites in the most powerful and well-organized farming villages extend their influence over their neighborhoods (Spencer 2010; Borcan, Olsson, and Putterman 2019). During early history, an earlier starting date for Neolithic agriculture (and hence a lower $\tau_{j}$ ) will thus imply a relatively high level of productivity in Equation (1) since the productivity growth process has been progressing for a longer time.

However, a second crucial assumption in our model is that an early transition to agriculture also has an offsetting negative impact by lowering the maximum productivity potential $\tilde{A}_{j}$. More formally, we assume that $\tilde{A}_{j}\left(\tau_{j}\right)$ is a function such that $\tilde{A}_{j}^{\prime}\left(\tau_{j}\right)>0$. Our argument for the different maximum productivity levels in this model rests on Lagerlöf (2016) who develops a theoretical mechanism through which it is shown that countries that made an earlier transition to states will have a lower productivity potential $\tilde{A}_{j}$ and income level $Y_{j t}$ in the long run. As has been 
demonstrated in recent work (Borcan Olsson, and Putterman 2019), there is a tight, positive empirical relationship between the historical date of transition to agriculture and the subsequent transition to states. Hence, an early $\tau_{j}$ in our setting also means an early emergence of a state.

In Lagerlöf's model, countries that transit into statehood early are always autocratic in the sense that a single dominant group has grabbed power and invests in extractive (taxing) capacity and in public goods, where only the latter advance economic development. In countries where states (and hence agriculture) emerged early, the government would over time build up substantially higher extractive capacity than in younger states. At a later date in history, democracy is introduced as an exogenous opportunity shock and government elites consider whether to adopt democracy, with an equal sharing of resources but with no costs of extractive capacity, or remain in autocracy. The large sunk investments under high extractive capacity in older states implies that elites in such countries are less prone to adopt democracy than in younger states, where the elites have less to lose. Hence, democracies tend to arise in younger states which are also able to reach a higher long-run level of public goods investment and income due to the absence of socially wasteful investments under unproductive extractive capacity. ${ }^{20}$

We propose that our assumption of $\tilde{A}_{j}^{\prime}\left(\tau_{j}\right)>0$ should be primarily thought of as reflecting Lagerlöf's mechanism via extractive capacity and the transition to democracy. If this mechanism is correct, we should not only find a negative long-run relationship between time since transition to agriculture and contemporary income levels, but also that a late transition to agriculture is positively associated with the adoption of democracy.

\section{Numerical Simulation}

Our theoretical framework can be used to make a comparative country (or regional) analysis where we analyze how the impact of time since transition to agriculture, $t-\tau_{j}$, changes from having a positive effect on relative productivity levels early in history, to having a negative impact later in history when all countries approach their maximum long-run productivity potential. In Online Appendix D, we provide a mathematical analysis of these time-dependent effects.

\footnotetext{
${ }^{20}$ There are other reasons why one might assume that an early transition to agriculture means a lower maximum productivity potential $\tilde{A}_{j}$; for an explanation based on the early farmers' historical migration process and spread of cultural norms along the collectivism-individualism scale, see Olsson and Paik (2016).
} 
In this section, we illustrate the dynamics of the logistic productivity function by performing a numerical simulation of the model. In the simulation, we assume $t \in\{1,2, \ldots 120\}$ centennial periods where $t=1$ might be thought of as $9900 \mathrm{BCE}$ and $t=120$ as $2000 \mathrm{CE}$. We consider the dynamics of three example countries, $\mathrm{A}, \mathrm{B}$, and $\mathrm{C}$, with agricultural transition dates $\tau_{A}=15(8500 \mathrm{BCE}), \tau_{B}=40(6000 \mathrm{BCE})$, and $\tau_{C}=65$ (3500 BCE). We assume $g=0.13$ and that maximum productivity potentials are $\tilde{A}_{A}=100, \tilde{A}_{B}=$ 130, and $\tilde{A}_{C}=160$.

The resulting dynamics of productivity are shown in Figure 6 . At a very early date in history such as $4000 \mathrm{BCE}$, Country A has already reached its maturity stage and has advanced way ahead of Country B, which is still in an early take-off stage. Country $\mathrm{C}$ is at this time still in a pre-agricultural stage.

The comparisons between productivity levels for the years $2000 \mathrm{BCE}$, $100 \mathrm{CE}$, and $2000 \mathrm{CE}$ are shown in Figure 6. In $2000 \mathrm{CE}$, Country C has now made a transition to agriculture, Country $B$ has had a period of very rapid productivity growth, but is still behind Country A, which has reached its stagnation phase. Overall, there is at this time still a positive relationship between time since transition to agriculture and productivity levels. In $100 \mathrm{CE}$, Country B has overtaken Country A and Country C is in its most rapid development phase. By $2000 \mathrm{CE}$, Country C has overtaken both A and $\mathrm{B}$ and there is now a negative relationship between time since transition and levels of productivity.

\section{Historical Records}

These simulation results are consistent with the historical divergence between regions in the Western core that experienced early agricultural adoption (the Middle East) and those that experienced it late (Western Europe) even before the early modern period. The narratives on the early state formation in the Middle East (Wittfogel 1957; Carneiro 1970; Kennedy 1981) indeed suggest that the earliest agricultural societies in the Middle East also witnessed the rise of civilizations first in the form of autocratic states, and that these differed from those that arose much later in Western Europe.

In our model, early adopters have lower maximum productivity potential due to higher extractive capacity built up in the long run under autocracy. This key assumption finds support in the historical comparative works looking at the societies of the Middle East and Western Europe. For example, in an overview of state building literature in the Middle East, Blaydes (2017) importantly makes the relevant connections between 
A)

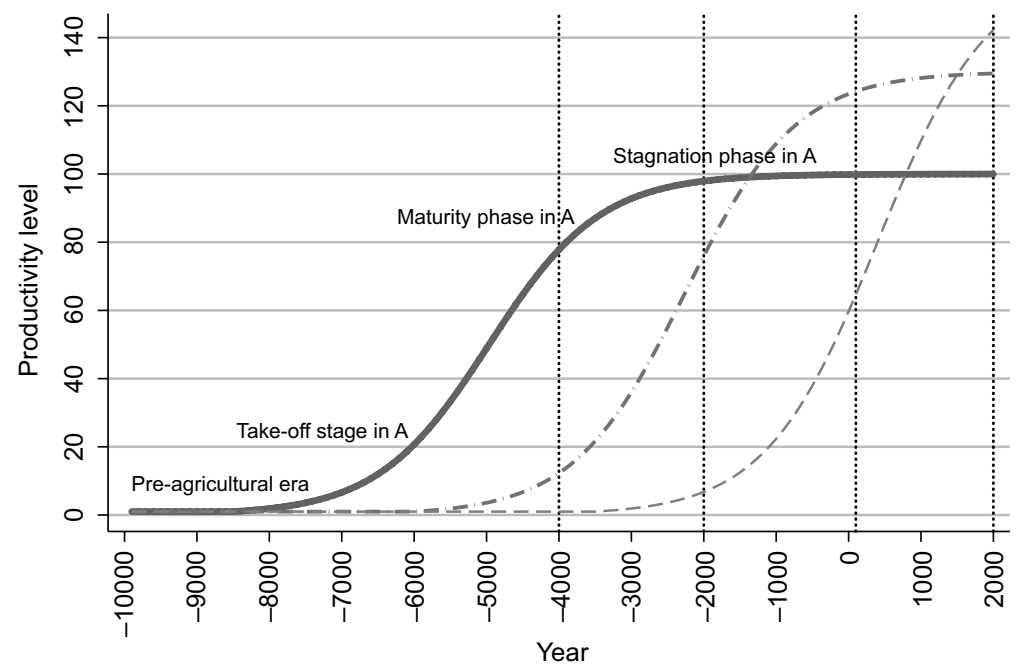

\begin{tabular}{rr}
- Country A \\
------ Country B \\
\hline-- Country
\end{tabular}

B)

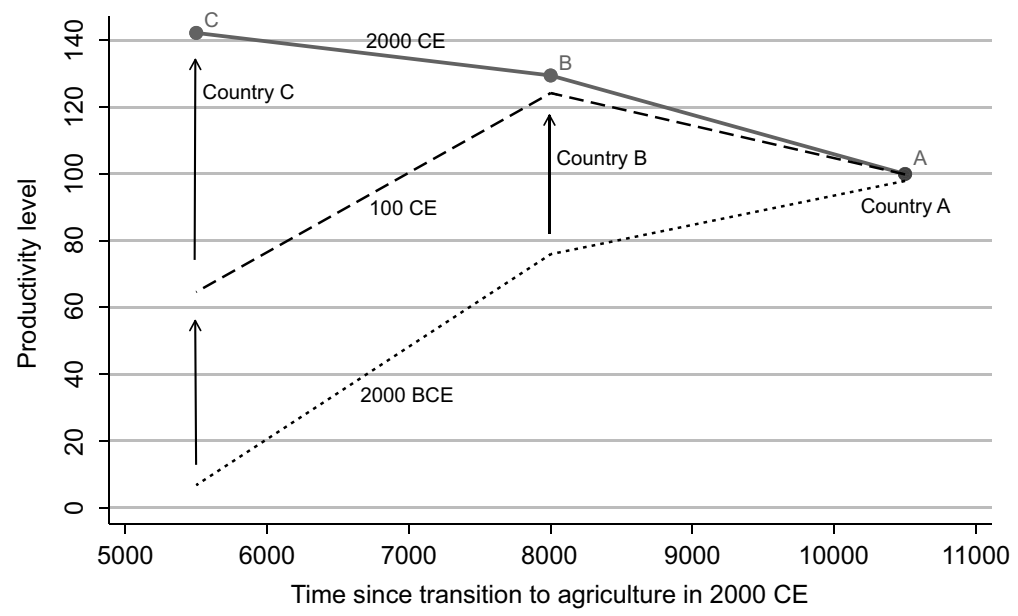

$\longrightarrow \ldots$ Productivity in $2000 \mathrm{CE}$
$\ldots \ldots . .$.

FIGURE 6

\section{SIMULATION OF LOGISTIC PRODUCTIVITY FUNCTION AND ITS CHANGING IMPACT OVER TIME FOR THREE EXAMPLE COUNTRIES}

Notes: The figures provide a simulation of the logistic productivity function for three example countries $(\mathrm{A}, \mathrm{B}, \mathrm{C})$ with different dates of transition to agriculture and different maximum productivity potentials, as specified in the text. Panel (a) shows the level of productivity over time for the three example countries whereas Panel (b) shows the implied scatter plots with connected lines at three different dates; $2000 \mathrm{BCE}, 100 \mathrm{CE}$, and $2000 \mathrm{CE}$. A key insight from the figure is that the relationship between productivity levels and time since transition to agriculture changes from being positive to being negative over time.

Source: Based on authors' simulations, which are available upon request. 
early agricultural adoption, rise of autocratic states, and institutional features that stagnated economic development in the Middle East in the long run. The author argues that the rulers in the Middle East long maintained strong grips on fiscal capacity and bureaucracy inherited down from one period to another, in part aided by constant threats of nomadic invasions from the desert peripheries.

Blaydes (2017) specifically identifies two institutional features across the polities in the Middle East that could develop because of the autocrats' superior bureaucratic and financial position during the Islamic Golden Age: the use of foreign slave soldiers (i.e., mamluks) and state control over agricultural land (i.e., iqta). According to the author, the rulers bought military support rather than develop feudalism as in Europe, where kings conceded their land and political power to the local lords for military support. Agricultural land also belonged to the state; unlike Europe's landed gentry, the military slaves who were assigned tax rights to the land in return for their service thus had no incentives to provide public goods or invest in the land. These institutional inheritances in history are aligned with autocrats' incentives to keep both land and political power highly centralized, and are in line with our model. $^{21}$

Blaydes and Chaney (2013) further attribute the divergence in political stability and representation in Western Europe vs. the Middle East to the rise of feudal institutions and their forms of executive constraint. The authors find that this unique institutional framework with checks on the sovereign was noticeably absent in the Middle East with important consequences on the region's stagnation in the long run. Western Europe's sustained economic development since the beginning of the early modern period and onwards, on the other hand, is well documented in the literature (Acemoglu, Johnson, and Robinson 2005; North and Weingast 1989). In Europe, political fragmentation and representative institutions found under weak rulers furthermore led to political innovations such as modern democracy (Cox 2017; Stasavage 2016). The case of Europe again fits the setting in our model; there is relatively little extractive capacity built and the elites find it less costly to switch from autocracy to democracy.

${ }^{21}$ Other works on the Middle East's stagnation relative to Europe offer explanations based on the Islamic law (Kuran 2010), Islam's religious legitimacy over the Middle Eastern politics (Rubin 2017), as well as its collectivistic culture (Greif 1994). These alternative explanations relate to our model predictions; both legal and theocratic institutions found under Islamic traditions also witness the concentration and entrenchment of power among the few, and the collectivistic culture emphasizing social ties can similarly describe the characteristics of early agricultural societies under threat of predation. 


\section{CONCLUDING REMARKS}

In this article, we document a historical reversal of fortune within the Western agricultural core region. We show that countries which adopted agriculture and complex civilizations early in history tend to be poorer today than countries in the periphery that adopted agriculture late. By focusing our analysis on variations within an independent core region, we advance Diamond's seminal work on the impact of the Neolithic Revolution, and the subsequent economics literature that showed the long-term importance of early agriculture on contemporary institutional development and economic performance. We further demonstrate that there is a strong negative association between time since agricultural transition and current income levels within Western countries, with a particularly strong relationship in Italy, Spain, and Turkey.

Importantly, we find that the economic reversal appears to have started to emerge already by $1500 \mathrm{CE}$, that is, before the Western colonization and industrialization, and then grew stronger over time. Hence, the very large income differences that emerged during the last 500 years seem to be partly rooted in development trajectories dating back to the Neolithic. In addition, we explore the existence of democratic institutions as one of the channels that can explain the income levels today. Using standard regression techniques, we find that an early transition to agriculture strongly predicts low levels of democracy already by $1500 \mathrm{CE}$, and that this relationship persists when we use composite data from the twentieth century.

Finally, we present a theoretical framework with a growth model in accordance with our empirical findings. In the model, regions witnessing early emergence of agriculture enjoy a strong initial boost to economic development and emergence of hierarchical states. They are, however, eventually overcome by late adopters that develop less extractive capacity and more inclusive political institutions that are conducive for innovation and superior productivity levels in the long run. These predictions are in line with some of the stylized facts comparing the diverging development paths between the Middle East and Western Europe during the early modern period, and provide one explanation for the reversal presented in this article. We believe that together they may serve as a reference point for further future research on the long-run mechanisms that generated the Western reversal.

\section{REFERENCES}

Acemoglu, D., Simon Johnson, and James Robinson. "The Rise of Europe: Atlantic Trade, Institutional Change, and Economic Growth." American Economic Review 95, no. 3 (2005): 546-97. 


\section{The Long-Run Impact of Early Agriculture}

Acemoglu, Daron, and James Robinson. Why Nations Fail: The Origins of Power, Prosperity and Poverty. New York: Crown Publishers, 2012.

Ammerman, Albert, and Luigi Luca Cavalli-Sforza. The Neolithic Transition and the Genetics of Populations in Europe. Princeton, NJ: Princeton University Press, 1984.

Ashraf, Quamrul, and Oded Galor. "Dynamics and Stagnation in the Malthusian Epoch.” American Economic Review 101, no. 5 (2011): 2003-41.

—. "The Out of Africa Hypothesis, Human Genetic Diversity, and Comparative Economic Development." American Economic Review 103, no. 1 (2013): 146.

Ashraf, Quamrul, and Stelios Michalopoulos. "Climatic Fluctuations and the Diffusion of Agriculture." Review of Economics and Statistics 97, no. 3 (2015): 589609.

Ashraf, Quamrul, Omer Özak, and Oded Galor. "Isolation and Development." Journal of the European Economic Association 8, nos. 2-3 (2010): 401-12.

Bellwood, Peter. First Farmers: The Origins of Agricultural Societies. Malden, MA: Blackwell Publishing, 2005.

Blaydes, Lisa. "State Building in the Middle East." Annual Review of Political Science 20 (2017): 487-504.

Blaydes, Lisa, and Eric Chaney. "The Feudal Revolution and Europe's Rise: Political Divergence of the Christian and Muslim Worlds before 1500 CE." American Political Science Review 107, no. 1 (2013): 16-34.

Blaydes, Lisa, and Christopher Paik. "The Impact of Holy Land Crusades on State Formation: War Mobilization, Trade Integration, and Political Development in Medieval Europe." International Organization 70, no. 3 (2016): 551-86.

Bleaney, Michael, and Arcangelo Dimico. "Biogeographical Conditions, the Transition to Agriculture, and Long-Run Growth." European Economic Review 55, no. 7 (2011): 943-54.

Borcan, Oana, Ola Olsson, and Louis Putterman. "State History and Economic Development: Evidence from Six Millennia." Journal of Economic Growth 23, no. 1 (2018): 1-40.

- "Transition to Agriculture and First State Presence: A Global Analysis." Working Paper, University of East Anglia, Norwich, UK, 2019.

Borsch, Stuart J. The Black Death in Egypt and England: A Comparative Study. Austin: University of Texas Press, 2005.

Bosker, Maarten, Eltjo Buringh, and Jan Luiten van Zanden. "From Baghdad to London: Unraveling Urban Development in Europe, the Middle East, and North Africa, 800-1800." Review of Economics and Statistics 95, no. 4 (2013): 1418-37.

Bowles, Samuel, and Jung-Kyoo Choi "Coevolution of Farming and Private Property during the Early Holocene." Proceedings of the National Academy of Sciences of the USA 110, no. 22, (2012): 8830-35.

Carneiro, Robert L. "A Theory of the Origin of the State.” Science 169 (1970): 73338.

Christakos, George, Ricardo Olea, Marc Serre, Hwa-Lung Yu, and Lin-Lin Yang. Interdisciplinary Public Health Reasoning and Epidemic Modelling: The Case of Black Death Berlin: Springer, 2005.

Clark, Gregory. A Farewell to Alms: A Brief Economic History of the World. Princeton, NJ: Princeton University Press, 2008. 
Conley, Timothy. "GMM Estimation with Cross-Sectional Dependence." Journal of Econometrics 92 (1999): 1-45.

Cox, Gary. "Political Institutions, Economic Liberty and the Great Divergence." Journal of Economic History 77, no. 3 (2017): 724-55.

Diamond, Jared. Guns, Germs and Steel: The Fates of Human Societies. New York: Norton, 1997.

Gerring, John, Philip Bond, William T. Barndt, and Carola Moreno. "Democracy and Economic Growth: A Historical Perspective." World Politics 57 (2005): 323-64.

Greif, Avner. "Cultural Beliefs and the Organization of Society." Journal of Political Economy 102, no. 5 (1994): 912-50.

Harlan, Jack. The Living Fields: Our Agricultural Heritage. Cambridge, UK: Cambridge University Press, 1995.

Hibbs, Douglas A., and Ola Olsson. "Geography, Biogeography, and Why Some Countries Are Rich and Others Are Poor." Proceedings of the National Academy of Sciences of the USA 101, no. 10 (2004): 3715-20.

Jones, Eric. The European Miracle: Environments, Economies and Geopolitics in the History of Europe and Asia. Cambridge, UK: Cambridge University Press, 1981.

Kennedy Hugh. The Early Abbasid Caliphate: A Political History. London: Croom Helm, 1981.

Kennedy, Jay. The Rise and Fall of the Great Powers: Economic Change and Military Conflict from 1500 to 2000. New York: Vintage Books, 1988.

Kuran, Timur. The Long Divergence: How Islamic Law Held Back the Middle East. Princeton, NJ: Princeton University Press, 2010.

Lagerlöf, Nils-Petter. "Statehood, Democracy and Preindustrial Development." Journal of Economic Dynamics and Control 67 (2016): 58-72.

Landes, David S. The Wealth and Poverty of Nations: Why Some Are So Rich and Others So Poor. New York: W.W. Norton \& Company, 1998.

La Porta, Rafael, Florencio Lopez-De-Silanes, and Andrei Shleifer. "Corporate Ownership Around the World.” Journal of Finance 54, no. 1(1999): 471-517.

Matranga, Andrea. "The Ant and the Grasshopper: Seasonality and the Invention of Agriculture." Mimeo, 2017.

Mokyr, Joel. The Lever of Riches: Technological Creativity and Economic Progress. New York: Oxford University Press, 1990.

Morris, Ian. Why the West Rules - For Now: The Patterns of History and What They Reveal About the Future. London: Profile Books, 2010.

North, Douglass C. Institutions, Institutional Change and Economic Performance. Cambridge, UK: Cambridge University Press, 1990.

North, Douglass C., and Barry R. Weingast. "Constitutions and Commitment: The Evolution of Institutions Governing Public Choice in Seventeenth-Century England." Journal of Economic History 49, no. 4 (1989): 803-32.

Olsson, Ola, and Douglas A. Hibbs, Jr. "Biogeography and Long-Run Economic Development." European Economic Review 49, no. 4 (2005): 909-38.

Olsson, Ola, and Christopher Paik. "Long-Run Cultural Divergence: Evidence from the Neolithic Revolution.” Journal of Development Economics 122 (2016): 197-213.

Olsson, Ola, and Christopher Paik. "Replication: A Western Reversal Since the Neolithic? The Long-Run Impact of Early Agriculture." Ann Arbor, MI: Interuniversity Consortium for Political and Social Research [distributor], 2019-12-11. https://doi.org/10.3886/E116643V1. 


\section{The Long-Run Impact of Early Agriculture}

Pinhasi, Ron, Joaquim Fort, and Albert J. Ammerman. "Tracing the Origins and Spread of Agriculture in Europe." PLOS Biology 3, no. 12 (2005): 2220-28.

Pomeranz, Kenneth. The Great Divergence: China, Europe, and the Making of the Modern World Economy. Princeton, NJ: Princeton University Press, 2000.

Putnam, Robert D., Robert Leonardi, and Raffaella Y. Nanetti. Making Democracy Work: Civic Traditions in Modern Italy. Princeton, NJ: Princeton University Press, 1993.

Putterman, Louis. (2006). Agricultural transition data set. Available at http://www. econ.brown.edu/fac/louis putterman/agricultural\%20data\%20page.htm.

—. "Agriculture, Diffusion and Development: Ripple Effects of the Neolithic Revolution." Economica 75, no. 300 (2008): 729-48.

Putterman, Louis, and David Weil. "Post-1500 Population Flows and the Long-Run Determinants of Economic Growth and Inequality." Quarterly Journal of Economics 125, no. 4 (2010): 1627-82.

Rostow, Walt Whitman. The Stages of Economic Growth: A Non-Communist Manifesto. Cambridge: Cambridge University Press, 1960.

Rubin, Jared. Rulers, Religion and Riches: Why the West Got Rich and the Middle East Did Not. New York: Cambridge University Press, 2017.

Scott, James C. Against the Grain: A Deep History of the Earliest States. New Haven, CT: Yale University Press, 2017.

Smith, Bruce D. The Emergence of Agriculture. New York: Scientific American Library, 1998.

Spencer, Charles I. "Territorial Expansion and Primary State Formation." PNAS 107, no. 16 (2010): 7119-26.

Spolaore, Enrico, and Romain Wacziarg. "How Deep Are the Roots of Economic Development?" Journal of Economic Literature 51, no. 2 (2013): 1-45.

Stasavage, David. "Representation and Consent: Why They Arose in Europe and Not Elsewhere." Annual Review of Political Science 19 (2016): 145-62.

Voigtländer, Nico, and Hans-Joachim Voth. "The Three Horsemen of Riches: Plague, War, and Urbanization in Early Modern Europe.” Review of Economic Studies 80, no. 2 (2013): 774-811.

Weisdorf, Jacob L. (2005). "From Foraging to Farming: Explaining the Neolithic Revolution.” Journal of Economic Surveys 19, no. 4 (2005): 561-86.

Wittfogel, Karl A. Oriental Despotism: A Comparative Study of Total Power. New Haven, CT: Yale University Press, 1957. 